The Moral Foundations of Human Rights Attitudes

\begin{tabular}{|c|c|}
\hline Journal: & Political Psychology \\
\hline Manuscript ID & POPS-OA-02-2018-3383.R1 \\
\hline Wiley - Manuscript type: & Original Article \\
\hline Broad Area of Study: & Ideology/Values \\
\hline $\begin{array}{r}\text { Epistemological and } \\
\text { Methodological Preference: }\end{array}$ & $\begin{array}{l}\text { Experimental < Quantitative, Surveys, Assessment Construction < } \\
\text { Quantitative }\end{array}$ \\
\hline Specific Research Interests: & Personality/individual differences, Ideology and values \\
\hline \multicolumn{2}{|l|}{ Geographical Specialization: } \\
\hline Abstract: & $\begin{array}{l}\text { Human rights are claimed to be innate and based on moral principles. } \\
\text { Human rights attitudes have been shown to be related to political ideology, } \\
\text { but there have been few studies investigating their relationship with } \\
\text { morality. Using moral foundations theory, we examine whether morals can } \\
\text { predict human rights attitudes across two studies. The first study used } \\
\text { questionnaires to show that human rights are based exclusively on } \\
\text { individualising moral foundations; however, increases in individualising and } \\
\text { decreases in binding foundations predict increases in human rights } \\
\text { endorsement. Moral foundations also mediated the relationship between } \\
\text { political identification and human rights. Both individualising and binding } \\
\text { foundations performed a role in explaining the lower endorsement of } \\
\text { human rights by conservatives as compared to liberals. The second study } \\
\text { used textual analysis of newspaper articles to show that human rights } \\
\text { related articles contained more moral language than other articles, in } \\
\text { particular for the individualising foundations. Conservative newspapers had } \\
\text { a greater use of binding foundations in human rights articles than liberal } \\
\text { newspapers. }\end{array}$ \\
\hline
\end{tabular}




\section{The Moral Foundations of Human Rights Attitudes}

Running Head: The Moral Foundations of Human Rights Attitudes

Keywords: morality; moral foundations theory; human rights; moral foundations dictionary; human rights questionnaire; moral foundations questionnaire;

(Words:8,963) 


\begin{abstract}
Human rights are claimed to be innate and based on moral principles. Human rights attitudes have been shown to be related to political ideology, but there have been few studies investigating their relationship with morality. Using moral foundations theory, we examine whether morals can predict human rights attitudes across two studies. The first study used questionnaires to show that human rights are based exclusively on individualising moral foundations; however, increases in individualising and decreases in binding foundations predict increases in human rights endorsement. Moral foundations also mediated the relationship between political identification and human rights. Both individualising and binding foundations performed a role in explaining the lower endorsement of human rights by conservatives as compared to liberals. The second study used textual analysis of newspaper articles to show that human rights related articles contained more moral language than other articles, in particular for the individualising foundations. Conservative newspapers had a greater use of binding foundations in human rights articles than liberal newspapers.
\end{abstract}




\section{Introduction}

Human rights are frequently justified, explained and discussed as a codified version of moral obligations. The Universal Declaration of Human Rights (UDHR) was adopted by the United Nations general assembly in 1948. Its first sentence sets the stage that human rights are "equal and inalienable" based on the "inherent dignity" of all people (UN General Assembly, 1948). Morsink (1999) clarifies that for the UDHR human rights are "moral rights" that people have "because of their membership in the human family, not because of any external force or agency" (p. 290). The field of moral psychology (Graham, 2013) includes studying the properties of the mind that cause moral behaviour. Some theories in moral psychology describe these features as innate systems in humans, shaped by evolutionary processes (Bloom, 2012). One such theory of moral behaviour is moral foundations theory (MFT) (Graham, 2013; Haidt \& Graham, 2007). Using this theory as a basis for morality we investigate the relationship between moral opinions and human rights attitudes.

\section{Moral Foundations Theory}

Moral foundations theory describes all moral judgements as being based on one (or more) moral foundations (Graham et al., 2013; Haidt, 2012). The foundations are generally considered to be:

- care vs. harm,

- fairness vs. cheating,

- loyalty vs. betrayal,

- authority vs. subversion,

- $\quad$ sanctity vs. degradation. 
The care and fairness foundations are often grouped as individualising moral foundations related to protection of individuals, individual rights and welfare. The loyalty, authority and sanctity foundations are grouped into binding foundations concerning the protection of the group or institution, and avoidance of selfishness by binding individuals into roles or duties (Graham et al., 2011; Graham, Haidt, \& Nosek, 2009).

Moral foundations theory (MFT) is based on a view of moral judgement as primarily stemming from intuitions not reasoning; for example the social-intuitionist theory of moral judgement (Haidt, 2001). MFT argues that a brain module in humans is responsible for each moral foundation. It does not require the brain modules to be localised in a specific brain region, nor does it require the innate basis to be hard-wired or un-malleable. Instead MFT argues that the brain is "organized in advance of experience" through evolutionary processes (Graham et al., 2013, p. 61). Hence people have a mental preparedness to learn moral values, principles or rules when subjected to relevant environmental influences. This leads to a key feature of moral foundations theory: despite universal foundations, individuals will have different weightings for each foundation due to differences in environmental influences, such as the culture of the society during upbringing (Graham et al., 2013). For example, some people may weigh the care foundation as more important than sanctity, although it is likely that they will still make some moral judgements based on sanctity (Haidt, 2012).

\section{Descriptive not Normative}

The fields of moral psychology in general and MFT in particular are descriptive not normative (Graham et al., 2013). Using empirical results, they aim to describe the features of how morality actually works in people and not how it should work. Normative questions 
of what should be praised or condemned fall into the domain of philosophy and not moral psychology, and are not addressed directly by MFT (Graham et al., 2013). However, some moral psychology studies have discussed how descriptive ideas may inform normative theories (Greene, 2003; Haidt \& Graham, 2009). The ideas about the morality of human rights expressed by the authors of the UDHR are correctly understood as normative arguments. The Commission on Human Rights wrote the UDHR as a document containing what human rights ought to be, based on their view of what morality ought to be (Winter \& Prost, 2013). As with the study of morality, normative arguments about human rights fall into philosophy or law (Shelton, 2013) and the related descriptive field is human rights attitudes (McFarland, 2015). As with moral theories, some normative work on justifications and explanations of human rights is based on empirical evidence and ideas from descriptive studies (Finkel \& Moghaddam, 2005). With an understanding that the distinction between the descriptive and normative can be murky, we aim to stay clearly in the descriptive domain in the studies performed and discussion offered.

\section{Human Rights Attitudes}

Two important questions in the study of human rights attitudes are which human rights are being considered and how to group these rights. There are many different definitions of human rights, including those in the UDHR, international conventions, regional declarations and conventions, and national law. These contain similar but not identical rights (McFarland, 2015). With so many overlapping definitions of human rights, each of which contains many rights, it is important to be clear what rights are being referred to when measuring human rights attitudes. 
Cassin split the rights contained in the UDHR into six categories: principles, individual rights, relational rights, public rights, socio-economic rights and societal order (Doise, Spini, \& Clémence, 1999). Out of these categories, principles and societal order do not contain specific rights but instead general principles of the rights and how they apply. Studies looking at HR attitudes have broadly confirmed that understanding and endorsement of human rights fits with these categories. However, high correlations between different categories often results in fewer distinct groupings than Cassin envisioned. Doise et al. (1999) found understanding of the rights from the UDHR resulted in five groupings: principles, basic rights, individual rights, social rights and societal order. Crowson (2004) found a three-factor structure for endorsement of human rights principles that was labelled Personal Liberties, Civilian Constraint and Social Security. Diaz-Veizades et al. (1995) found endorsement of human rights showed four factors that they labelled Social Security, Civilian Constraint, Equality, and Privacy. The Social Security factor was related to rights associated with ensuring an adequate standard of living (for example, health care or employment). The Civilian Constraint factor was related to civil and political rights (for example, freedom of expression or political imprisonment). The Equality factor was related to equal access to rights without discrimination (for example, non-discrimination by gender in marriage). Most items in the Privacy factor related to individual privacy, however it also contained items that were unrelated to privacy. These factors are reasonably consistent with the United Nations classification of human rights into two conventions: the first for civil and political rights, and the second for social, economic and cultural rights, with equality as a basic principle for both. 
It is necessary to recognise the strengths and weaknesses of the methods used to assess human rights attitudes. In psychological studies several questionnaires for assessing attitudes to human rights have been developed (McFarland, 2010, 2015; McFarland \& Mathews, 2005). The Human Rights Scale (HRS; Moghaddam \& Vuksanovic, 1990) and Human Rights Questionnaire (HRQ; Diaz-Veizades et al., 1995) attempt to measure agreement with the principles of the UDHR. Doise, Spini, Jesuino, and Ng (1994) used a scale that investigates understanding and agreement with verbatim excerpts from the UDHR. One concern with all these scales is that agreement with the principles is often very high amongst all participants (McFarland, 2015). The Attitudes Toward Human Rights Index (ATHRI; Getz, 1985) attempts to solve this by including controversial applications of human rights, but this is generally not successful (McFarland, 2015). Another problem with both the HRS and ATHRI is that they include statements that are not widely accepted as human rights (McFarland, 2015).

\section{Human Rights Attitudes and Morality}

Despite evidence that both theories of morality and human rights are related to personality traits and political orientation, there has been very little work looking at how moral judgements are related to human rights attitudes. Kohlberg's (1969) theory of moral reasoning describes a progression of moral reasoning increasing through levels up to the highest level of principled moral reasoning which conceives of morality as reducible to justice. Scores on tests for principled moral reasoning, the Defining Issues Test (DIT; Rest, 1986) and a revised version (DIT2; Rest, Narvaez, Thoma, \& Bebeau, 1999), have been investigated as predictors of human rights attitudes. Getz (1985) showed a correlation between the DIT scores for principled moral reasoning and the ATHRI measure of human rights endorsement. McFarland and Mathews (2005), and McFarland et al. (2012) showed 
weak correlations between DIT2 scores with commitment and restriction of human rights but no relation to endorsement of human rights principles.

The development of moral foundations theory presents an opportunity to explain the intuition, shared by the writers of the UDHR, that human rights are based on an innate sense of morality, while also explaining the differences in human rights attitudes present between political ideologies. This study uses a version of moral foundations theory that includes only the main five foundations listed earlier (Graham et al., 2013). Although the liberty foundation (see Graham et al., 2013 for an overview) may appear relevant to human rights attitudes, it is not considered here because it is most strongly weighted in individuals that identify as libertarians (Iyer, Koleva, Graham, Ditto, \& Haidt, 2012) who are unlikely to be significantly represented in the population samples. The liberty foundation is also newer and most instruments for measuring moral foundations weightings do not include it.

The first question investigated was whether attitudes to human rights are moral attitudes as opposed to attitudes without a moral component. Second, if human rights attitudes are based on moral intuitions, which of the moral foundations are they based on? Our hypothesis for the first question is that human rights are seen as moral issues. For the second, because human rights were conceived and implemented as rights to protect individuals from states, individualising and not binding foundations will underlie all human rights. The next question to be investigated is how individuals' weightings of moral foundations interact with the moral principles that human rights are based upon to show differences in human rights attitudes. We hypothesize that because human rights are based on individualising foundations, endorsement of human rights will be positively correlated with weightings for the individualising foundations. However, the use of human rights in any 
situation is always a trade-off unless the situation is entirely uncontroversial. People that highly value binding moral foundations will perform trade-offs between human rights and other factors not represented in human rights leading to an inverse correlation between human rights endorsement and binding moral foundations.

\section{Politics, Morality and Human Rights}

The relationships between political attitudes and MFT weightings (Graham et al., 2009; Graham, Nosek, \& Haidt, 2012), and between politics and human rights attitudes have been studied extensively (McFarland, 2015). The precise relationship between moral foundations and political ideology varies across studies. However, two consistent features are present: the weightings for individualising foundations are strongest amongst liberals but reduce for conservatives, and the inverse holds for the binding foundations. MFT has also been investigated in relation to opinions on specific political topics, including environmental attitudes (Feinberg \& Willer, 2012; Wolsko, Ariceaga, \& Seiden, 2016), "culture war" attitudes such as abortion, euthanasia, and animal testing (Koleva, Graham, Iyer, Ditto, \& Haidt, 2012), stem cell research (Clifford \& Jerit, 2013), whistle-blowing (Waytz, Dungan, \& Young, 2013), and attitudes towards the poor (Low \& Wui, 2015). Human rights attitudes are also correlated with political attitudes and ideology. Cohrs et al. (2007) showed greater willingness to restrict human rights and a lower importance of human rights for supporters of right-wing political ideology. In the USA Democrats are more likely to rate promoting and defending human rights as important than Republicans (McFarland, 2015).

We investigated the relationship between politics, moral foundations and human rights attitudes with a hypothesis that moral foundations weightings better explain the differences in human rights attitudes commonly attributed to politics. MFT is often described as a 
cause of differences in political ideology (Graham et al., 2013), however Smith, Alford, Hibbing, Martin, and Hatemi (2017) provide evidence that political ideology causes differences in moral foundations weightings (although see Haidt (2016) for some concerns with the data). We are agnostic about the causal relationship between politics and moral foundations in relation to the work presented here. Our hypothesis is that human rights are seen as moral principles and hence are better explained by MFT than political ideology.

\section{Study 1 - Moral Foundations and Human Rights Questionnaires}

The first study investigates the relationship between endorsement of human rights principles and moral foundations using online questionnaires.

\section{Participants}

In study 1a participants were undergraduate students at XXX and received course credit for participation. 162 participants (141 female) completed the questionnaire but 12 were excluded because they did not include any answers for any of the free text response questions leaving 150 responses. In study $1 \mathrm{~b}$ participants from the United States were recruited using Amazon Mechanical Turk and received a fixed payment for participation. 151 participants (73 female; median age 29) completed the questionnaire but 6 were excluded for the same reasons as in study 1 a leaving 145 responses. Although a more even balance between male and female participants in study 1a would have been preferred there is little evidence that sex is a significant factor for any of the results reported, and the results are mostly consistent between study $1 \mathrm{a}$ and $1 \mathrm{~b}$.

\section{Questionnaire and Procedure}

Participants completed the questionnaire online on the Qualtrics website. The questionnaire contained 30 pages (shown in a random order), each with a statement 
describing a moral or human rights scenario and several questions about the scenario. In study 1a there were 15 moral scenarios, comprising part two of the Moral Foundations Questionnaire (MFQ; Graham et al., 2011) (excluding the attention check scenario), and 15 human rights scenarios from the Human Rights Questionnaire (HRQ; Diaz-Veizades et al., 1995). The human rights scenarios were selected as the five scenarios with highest loading to each of the Equality (for example "Everyone, without discrimination, has the right to equal pay for equal work"), Social Security (for example, "Everyone has the right to an adequate standard of living") and Civilian Constraint (for example, "There are times when censorship of the press is justified") factors as reported by Diaz-Veizades et al. (1995). HRQ was chosen as the best existing measure of human rights attitudes because it includes subscales for categories of rights and does not include scenarios unrelated to human rights (McFarland, 2015; compared with ATHRI and HRS). The source of the statement (MFQ, HRQ and relevant foundation/human rights factor) was not shown. For study $1 \mathrm{~b}$ three of the HRQ equality scenarios were substituted as results indicated very high agreement on the original scenarios across all participants; the other scenarios were identical. The substitution successfully resulted in lower agreement $(t(254)=9.02, p<.001)$ and a greater variance $(F=12.3, p=.001)$. For each statement participants rated their agreement (seven-point Likert scale from strongly disagree to strongly agree; coded so that higher values were endorsements of the moral foundation or human rights). Participants also reported why they agreed or disagreed, by selecting from a list of descriptions of the five moral foundations or none. For some of the scenarios (11 in study $1 \mathrm{a}, 8$ in study $1 \mathrm{~b}$ ) participants were also asked to briefly explain the reasons for their agreement or disagreement. Supplemental appendix S1 has full details of the statements. In study 1a four additional questions related to individual and government relevance or application of the scenario 
were asked. These questions were not asked in study $1 b$ and responses are not reported here. In addition, participants were asked their sex and how they identified politically on a seven-point scale from very liberal to very conservative, or libertarian or don't know/undisclosed (as commonly used in, for example, Davies, Sibley, \& Liu, 2014; Graham et al., 2011, 2009). In study $1 \mathrm{~b}$ participants were asked their age; age was not included in study 1 a as all participants were undergraduate students.

This study directly asked participants for reasons why they agree or disagree with the moral foundations and human rights statements. The aim of these questions was to determine which moral foundations underlie judgements in the human rights scenarios. A possible concern with the methodology is that if the responses were the results of moral intuitions not moral reasoning, as is theorised by the social intuitionist theory of morality (Haidt, 2001), directly asking participants for their reasons may elicit post-hoc justifications rather than the real foundation that the judgement is based upon. If this was the case, a greater response of none or choosing a response randomly, increasing any uncertainty in the results would be expected. Direct questions such as these have been used previously such as in validation of the moral foundations vignettes (Clifford, lyengar, Cabeza, \& SinnottArmstrong, 2015). However, to validate the methodology, we used the same question for the MFQ statements as with HRQ statements. If participants categorise the MFQ statements as intended by MFT then the answers to the same question for the HRQ statements should be reliable in explaining the reasoning underlying the endorsement of the human rights principle.

\section{Results}


The results presented here are for studies $1 \mathrm{a}$ and $1 \mathrm{~b}$ separately. We also performed similar analysis for the data from studies $1 \mathrm{a}$ and $1 \mathrm{~b}$ combined. The results for this combined analysis are included in the supplementary appendix S2. The results from the combined analysis do not differ significantly from the results for the individual studies.

\section{Endorsement of Moral Foundations and Human Rights}

Means, standard deviations and Chronbach's alphas for agreement with the statements used in study 1 are presented in Table 1 . A score of four indicates a neutral position between disagreement and agreement.

Table 1 here

\section{Relationship of Endorsement of Moral Foundations and Human Rights}

To investigate the relationship between moral foundations weightings and endorsement of human rights, linear regressions were computed. Sex, age (study $1 \mathrm{~b}$ only) and the average score for the individualising and binding moral foundations were used as predictors for human rights endorsement for each of the categories of human rights (Table 2). The dependent variable was the mean of five Likert responses so it had a limited range (1 to 7) and in some cases the mean was close to the edge of the range. Hence bootstrapping with 1000 samples was used to calculate bias-corrected significance and 95\% confidence intervals. Neither sex nor age had any significant effect on human rights endorsement in any of the regressions. As shown in Figure 1 (green points and lines), for the individualising moral foundations, in all cases except one, the results were as expected, with increases in the weighting of individualising moral foundations showing significant increases in the endorsement of human rights across all three categories of human rights. The one exception was in study 1a where there was no relationship between individualising foundations and 
the civil constraint measure $(b=-0.07, p=.43)$. For the binding moral foundations (Figure 1 purple points and lines), an increase in the weighting for the binding moral foundations was related to a reduction in endorsement of human rights across all categories of human rights in both studies.

Figure 1 here

Table 2 here

\section{Reasoning on Opinion}

A breakdown of the reasons for agreement/disagreement for each scenario is included in Table 3 for phase $1 \mathrm{a}$ and Table 4 for phase $1 \mathrm{~b}$. Single sample chi-squared tests were computed for each statement and all the results differ significantly from random at the $p<.001$ level after applying a Bonferroni correction for 30 comparisons. In general, the reasons given for the MFQ statements were based on the expected moral foundation. There were a significant number of choices of none, especially for sanctity and loyalty foundations, perhaps indicating moral-dumbfounding (Haidt, 2012). The only exception to the reason predicted by the design of the MFQ across both studies was for the Sex Roles statement. It was rated as related to fairness not authority as expected by the MFQ (also with a significant number of participants choosing none). This may be due to the low level of agreement with the Sex Roles statement (Study 1a: $M=3.5$, s.d.=1.8. Study $1 b: M=3.3$, s.d.=1.9). These results validate that the questions we asked about reasons for judgements can provide useful information about which moral foundation the decision was based upon.

Agreement/disagreement with the HRQ statements was explained by the fairness moral foundation most strongly, but also by care, especially for the social security category of human rights. The distribution of the answers as explained by the fairness and care 
foundations, and not spread across all moral foundations or the other category provides evidence that the participants viewed the human rights scenarios as questions about moral judgements. The only exception across both studies was the Property human rights scenario which had a significant number of responses for other. This may be because the most popular response for this statement was neither agree nor disagree (Study 1a: $M=4.1$, s.d.=16. Study $1 \mathrm{~b}: M=3.8$ s.d.=2.0). More specifically responses for judgements to the human rights scenarios were moral judgements that used the individualizing foundations and not the binding foundations.

Table 3 here

Table 4 here

\section{Politics and Human Rights}

In both studies $1 \mathrm{a}$ and 1b, few participants' political identification was libertarian (Study 1a: 2, Study 1b: 2) and a number of participants chose don't know (Study 1a: 33, Study 1b: 5). Subjects that identified as libertarian or don't know were excluded from the political analysis leaving 115 subjects for study $1 \mathrm{a}$ and 138 subjects for study $1 \mathrm{~b}$ with a political identification score from 1 (very liberal) to 7 (very conservative). Also consistent in both studies, the participants were significantly more liberal than the mid-point (4) of the scale (Study 1a: $M=3.3, t(114)=4.9, p<.001$; Study $1 \mathrm{~b}: M=3.1, t(137)=6.2, p<.001)$. There was only one participant in each study that responded as very conservative (a value of 7).

Figure 2 here

To investigate the relationship between political ideology and endorsement of human rights an analysis with individualising and binding moral foundations scores as mediators 
between political ideology and the overall human rights score was carried out. The analysis was run with the Process SPSS Macro version 2.15 (Hayes, 2013) with 5000 bootstrap samples. A single human rights score (the average of the three subscales) was used in this analysis because the scores for the three human rights subscales are correlated. The simple relationships between human rights, moral foundations and politics are shown in Figure 2 and the results of the mediation are summarised in Figure 3. In the total effects model politics had a significant negative effect on endorsement of human rights (Figure 3 path $c$, 1a: $\left.b=-0.16, t(113)=-4.75, p<.001, R^{2}=.17,1 \mathrm{~b}: b=-0.26, t(136)=-7.52, p<.001, R^{2}=.29\right)$ showing that individuals with more conservative political ideology had a lower endorsement of human rights. Politics also has a significant negative effect on individualising moral foundations scores (Figure 3 path $a_{1}, 1 \mathrm{a}: b=-0.16, t(113)=-2.92, p<.01, R^{2}=.07,1 \mathrm{~b}: b=-0.17$, $\left.t(136)=-3.78, p<.001, R^{2}=.09\right)$ showing more conservative political ideology reduces individualising moral foundations scores. Politics has a significant positive effect on binding moral foundations scores (Figure 3 path $a_{2}$, 1a: $b=0.26, t(113)=4.91, p<.001, R^{2}=.18,1 \mathrm{~b}$ : $\left.b=0.28, t(112)=6.50, p<.001, R^{2}=.24\right)$ showing more conservative political ideology increases binding moral foundations scores. The combined models where politics, individualising and binding moral foundations were predictors for human rights were significant (1a: $\left.F(3,111)=31.94, p<.001, R^{2}=.46,1 b: F(3,134)=50.05, p<.001, R^{2}=.53\right)$. In the combined models increases in HR endorsement were significantly predicted by increases in individualising MF scores (Figure 3 path $b_{1}, 1 \mathrm{a}: b=.15, t(111)=3.05, p<.01,1 \mathrm{~b}: b=.45$, $t(134)=7.74, p<.001)$ and decreases in binding MF scores (Figure 3 path $b_{2}, 1 a: b=-0.38$, $t(111)=-7.64, p<.001,1 b: b=-0.33, t(134)=-5.37, p<.0001)$. In the combined models the direct effect of politics (Figure 3 path $c^{\prime}$ ) on HR endorsement was no longer significant in study $1 a$ $(b=-0.04, t(111)=-1.24, p=.21)$ and reduced compared to the total effect in study $1 b(b=-0.09$, 
$t(134)=-2.48, p<.05)$. The indirect effect for individualising moral foundations (which is $a_{1} b_{1}$ ) explaining the relationship between politics and human rights was significant with $95 \%$ confidence intervals (1a: $b=-0.02[-0.05,-0.01], 1 b: b=-0.10[-0.17,-0.04])$. Similarly, the indirect effect of binding moral foundations $\left(a_{2} b_{2}\right)$ explaining the relationship between politics and human rights was also significant with $95 \%$ confidence intervals (1a: $b=-0.10$ [$0.15,-0.06], 1 b: b=-0.12[-0.18,-0.07])$.

It is important to note that the mediation analysis is performed on correlational data only and we are not using it to make claims about causation. The results show that moral foundations mediate the relationship between politics and human rights attitudes, which we interpret as moral foundations can explain differences in human rights endorsement better than political ideology alone.

Figure 3 here

\section{Discussion}

There is a clear relationship between individuals' scores on the moral foundations scenarios and their endorsement of human rights. Individuals expressing greater agreement with individualising moral foundations show a greater endorsement of human rights principles. This result makes sense because the individualising moral foundations (care and fairness) seem to be closely related to human rights principles, especially those of social security and equality. This intuition is borne out in the results where participants explained the reasons for their agreement were very strongly weighted to fairness for the equality subscale, and split between fairness and care for the social security subscale. 
Greater agreement with binding moral foundations showed a decrease in endorsement of human rights across all subscales. This is the case despite the reasons for agreement being stated as related to individualising and not binding moral foundations. One possible explanation for this discrepancy is that the stated reasons are not the reasons actually used (because moral judgements are based on intuition). However, this does not appear likely because reasons given by participants for the moral foundations statements accurately reflected the foundations that the statements were designed to test. Another explanation, discussed further in the general discussion, is that judgements on the human rights statements are based on comparison of the statement with an alternative that is related to binding foundations.

Political ideology has been shown to be a strong predictor of human rights attitudes (Cohrs et al., 2007; McFarland, 2015), with more conservative political views reducing endorsement of human rights. These results are replicated by the current study. Our study also shows similar results on the relationship between political ideology and moral foundations weightings to those reported previously (Franks \& Scherr, 2015; Graham et al., 2009; Nilsson \& Erlandsson, 2015). The mediation analysis shows that moral foundations weightings explain most of the relationship between politics and human rights endorsement. A theory where human rights principles are fundamentally moral principles, based on the moral foundations, can account for this result. Human rights, as with any set of moral principles, are based on a specific profile of moral foundations weightings. If an individual has weightings of moral foundations that are closer to those that are represented in human rights, they are likely to have a greater endorsement of human rights. Human rights are based on a weighting profile that has a significantly greater weighting for 
individualising than binding foundations. This more closely matches the profile for liberals than conservatives and hence explains the differences between liberals' and conservatives' endorsement of human rights.

\section{Study 2 - Analysis of Newspaper Articles}

Study 2 was designed to test the same hypotheses about the relationship of moral foundations theory to human rights as study 1 using an entirely different methodology. In study 2 newspaper articles were analysed in a quantitative manner to estimate the degree to which the articles are related to morality, and which moral foundation specifically.

\section{Materials and Procedure}

Leader articles from four UK national newspapers (The Guardian, The Independent, The Daily Telegraph, and The Daily Mail) were selected for analysis by searching the LexisNexis database (Nexis UK, n.d.). Articles were chosen from four consecutive date periods starting and ending in June for the years $2012 / 3,2013 / 4,2014 / 5$ and $2015 / 6$. For each date period the 50 most recent leader articles containing the phrase "human rights" were chosen as the human rights sample. If less than 50 leader articles contained this phrase all articles containing it were used. The non-human rights sample was the equivalent number of leader articles from each newspaper for each date period that did not contain the phrase "human rights". Full details of the queries are in supplemental appendix S3. Leader articles were selected as they are likely to be using arguments to persuade the reader in a way that is aligned with the newspaper's political ideology. The non-human rights articles were manually coded by the experimenters as being related to politics or to another topic (such as sport, entertainment or arts). $82 \%$ of the non-human rights articles were coded as related to politics. Articles were analysed using a specially written Matlab computer programme 
(available from https://github.com/dominic7852/MFDStat) to calculate the frequencies of words related to each of the five moral foundations, using the word lists from the moral foundations dictionary (MFD; Graham et al., 2009).

A Generalised Linear Model using the Negative Binomial distribution and a log link function was fitted to the absolute counts of words from the individualising and binding foundations. The log of the total words in each article was used as the exposure measure. As the frequencies of words for individualising and binding foundations were expected to be correlated the individualising and binding counts were treated as repeated measures with an unstructured covariance matrix. Type of article (HR or non-HR), politics of the source (liberal or conservative), moral foundation (individualising or binding), all 2-way interactions and the 3-way interaction between type of article, politics and moral foundation were included as predictors. The dispersion coefficient for the Negative Binomial distribution was estimated using maximum likelihood estimation.

\section{Results}

The fitted model results are shown in Table 5. The effect of the type of article $(F(1,2264)=225.4, p<.001)$ shows that human rights articles contained significantly more MFD words than non-human-rights articles ( $1.326 \%$ compared to $0.875 \%)$. The overall difference in the frequencies of individualising and binding words $\left(M_{b}=1.166 \%, M_{i}=0.995 \%\right.$, $F(1,2264)=42.2, p<.001)$ is likely due to the composition of the MFD and hence is not useful to interpret further. The interaction between article type and moral foundation is significant $(F(1,2264)=34.7, p<.001)$. Pairwise comparisons of the estimated means with HolmBonferroni correction for multiple comparisons shows that in non-human rights articles the frequency of binding words is significantly higher than individualising words $\left(M_{b}=1.017 \%\right.$, 
$\left.M_{i}=0.752 \%, t(2264)=8.3, p<.001\right)$. However, no difference between the frequencies in human rights articles is observed $\left(M_{b}=1.335 \%, M_{i}=1.316 \%, t(2264)=0.5, p<.634\right)$. This means that the frequency of individualising (compared to binding) words increased more in $H R$ articles than non-human rights articles.

Table 5 here

Figure 4 shows the percentage of binding and individualising MFD words for each article type and politics. Considering the differences between liberal and conservative newspapers, the main effect of politics was not significant $(F(1,2264)=0.6, p=.436)$. The interaction between politics and foundation is significant $(F(1,2264)=7.2, p=.007)$. Pairwise comparison of the estimated means shows that liberal newspapers have a higher frequency of individualising words than conservative newspapers $\left(M_{l}=1.039 \%, M_{c}=0.952 \%, t(2264)=2.1\right.$, $p=.037)$ but there was no difference in binding word frequencies $\left(M_{l}=1.140 \%, M_{c}=1.191 \%\right.$, $t(2264)=1.4, p=.161)$. A pairwise comparison of the estimated means with Holm-Bonferroni correction shows that for human rights articles conservatives use binding words significantly more than liberals $\left(M_{l}=1.261 \%, M_{c}=1.391 \%, t(2264)=2.0, p=.047\right)$. There was no significant difference in any of the other pairwise comparisons. Comparisons in Figure 4 shows that there is a higher frequency of binding than individualising words for both article types in conservative newspapers. However, in liberal newspapers the difference is eliminated $\left(M_{i}=1.373 \%, M_{b}=1.282 \%, t(2264)=1.6, p=.117\right)$ for human rights articles only.

Figure 4 here

\section{Discussion}


The use of word frequencies and text analysis within political psychology and related fields has been increasing over time. The ability to show evidence for the same hypothesis using a very different technique from questionnaires helps to reduce concerns that conclusions are artefacts of the questions. For example, Fetterman, Boyd, and Robinson (2015) used similar word frequency techniques to provide evidence of differences between power and affiliation mindsets between liberals and conservatives. The MFD is widely used across a number of studies (Day, Fiske, Downing, \& Trail, 2014; Graham et al., 2009; Waytz et al., 2013) to measure the moral values represented in the text it analyses, however some studies have raised concerns about the ability to measure moral values from text analysis (Neiman, Gonzalez, Wilkinson, Smith, \& Hibbing, 2016).

The use of words related to each moral foundation is an indicator of how much arguments based on that moral foundation are used to persuade. The newspaper articles analysed were all opinion articles from newspapers that give the newspaper's view on the issues discussed in the article. Hence the frequency of words related to the moral foundations is an indicator as to the use of moral arguments in these articles. The absolute frequency of words from the MFD is not meaningful because the words contained in the MFD are likely to have different base rate frequencies. Similarly, a single comparison of the frequencies for binding and individualising words is not meaningful. However, differences in frequencies for the binding or individualising words for different types of articles is useful as an indicator of the differences in the arguments used. The greater use of moral arguments in human rights provides evidence that human rights are based on moral opinions more than other topics (at least in the opinion of the newspapers). This difference is unlikely to be explained by a difference between politics related articles and other article types (such as 
sport or entertainment) because $82 \%$ of non-human rights were politics related. A greater increase in the use of individualising words than binding words in human rights articles shows that the moral arguments in these articles were more heavily based on the individualising moral foundations than those in non-human rights articles. Although care needs to be taken when drawing conclusions from the absence of a significant difference, there does not appear to be any overall difference in the use of moral arguments for liberal and conservative newspapers. Liberals and conservatives both use the same amount of moral language overall and both treat human rights more morally than other articles and to the same extent. Overall these results support the hypothesis that human rights attitudes are based on morality universally across the political spectrum, and they are especially related to individualising moral foundations.

Although there is no difference in the use of moral arguments between liberals and conservatives overall, when looking at the individualising and binding moral foundations differences appear. For human rights articles, conservatives use binding arguments more than liberals. This is in contrast to the overall effect for human rights articles where there is no difference in the use of individualising and binding arguments. An overall greater use for binding moral foundations by conservatives cannot explain this because non-human rights articles do not show greater use of binding moral foundations by conservatives compared to liberals. An explanation could be that for articles with any moral content conservatives use binding foundations in their argument more than liberals. However, another explanation is that conservatives often have a lower endorsement of human rights than liberals (McFarland, 2015) and it may be the differences in endorsement of human rights that provides an explanation. Conservatives may be more likely to be making arguments that are 
concerned with maintaining communities or societies, or that are critical of human rights. As human rights are based mainly on individualising moral foundations, arguments supporting human rights will be based on individualising foundations. Conversely arguments promoting social order or otherwise critical of human rights may be based on binding moral foundations. Hence articles that were overall more negative about human rights would have a greater reliance on binding moral foundations. While the results from study 2 are consistent with this hypothesis, it is not possible to test it directly using study 2 because no analysis of the articles' position as endorsing or criticising human rights was carried out. More discussion of this limitation and improvements to the studies follows in the general discussion.

\section{General Discussion}

Three studies using two different methodologies supports the hypothesis of a relationship between individuals' moral foundations weightings and their attitudes to human rights. All three studies provided evidence that human rights are viewed as moral principles based on individualising moral foundations. Moreover, a greater endorsement of individualising moral foundations showed a greater endorsement of all categories of human rights principles. Despite evidence that human rights principles are based on individualising moral foundations, increasing endorsement of binding moral foundations reduces endorsement of all categories of human rights.

While our studies cannot explain why weightings on seemingly unrelated moral foundations predict endorsement of human rights, one hypothesis is that when making judgements on the human rights principles individuals imagine alternatives based on binding moral foundations. Individuals' with a stronger endorsement of the binding moral 
foundations may imagine more alternatives or more strongly support those that they imagine, reducing endorsement of the human rights principle. For example, agreement with the statement "schools must not consider the sexuality of teachers when deciding to employ them" was related to the fairness foundation, but lower endorsement may be due to a moral disapproval of some sexualities. Moral judgements about sexual behaviour are normally considered to be based on the sanctity foundation (Graham et al., 2013). If endorsement with the statement is a trade-off between these alternatives, an individual's weighting of the sanctity foundation would predict their endorsement of this statement. Similarly, disagreement with the statement "there are times when detention of political prisoners may be necessary to ensure the maintenance of social order" was related to fairness and care foundations. However, greater agreement (lower endorsement of human rights principles) is likely to be related to greater weight put into the maintenance of the community or society; opinions that are likely based on the loyalty foundation. This explanation fits with McFarland and Mathews (2005) measures for human rights commitment, where subjects rated the relative importance of human rights to other goals that "focused on a national self-interest" (p. 373). The other goals may be based on binding moral foundations: for example, support for "Keeping undesirable people out of America" appears to be based on the loyalty foundation. When explicit alternative goals are presented, support for human rights is significantly lower than when human rights endorsement is measured in isolation (McFarland, 2015).

Another aspect to the studies was how differences in moral foundations weightings can explain the relationship between political identification and human rights. Study 1 confirmed the previously reported relationships between moral foundations theory and 
politics (Graham et al., 2011, 2009, 2012), and between politics and human rights endorsement (McFarland, 2015). Building on these results, mediation analyses showed that moral foundations weightings mediated the relationship between politics and human rights. This gives insight into the reasons for differences in support of human rights across the political spectrum, especially when endorsement of human rights principles is generally very high when looked at in isolation (Doise et al., 1999; Moghaddam \& Vuksanovic, 1990).

McFarland (2015) reviewed individual differences that predict support for human rights and categorised political ideology as a strong predictor. The results from study 1 suggest that moral foundations weightings may be added as strong predictor of human rights support and perhaps even replace political ideology as a predictor. However, the limited size of the population samples used in study 1 mean more work is needed to investigate if the results persist before conclusions of this sort should be drawn. Study 1 only investigated how MF weightings are related to human rights endorsement and not importance, commitment or behaviours which should also be tested. If moral foundations weightings remain good predictors of human rights attitudes, this has implications due to the multidimensional structure of moral foundations. As seen already in the results of study 1 , individualising foundations are better predictors of socio-economic rights and binding foundations are better predictors of civil and political rights. The specific relationship between foundations weightings and categories of human rights (or specific rights) might render a better understanding of how human rights are related to each other. The theoretical basis of moral foundations as being innate also has implications for human rights which are claimed to be innate. Firstly, this may support the claims of innateness of human 
rights, but secondly this evidence for human rights innateness may vary for different categories or specific rights.

\section{Limitations and extensions}

Although the results in these studies show strong relationships between human rights and MFT there are limitations which mean that caution is needed when drawing conclusions. The scale for human rights endorsement used in study 1 was a sample of the $H R Q$ questionnaire. While the HRQ sample used attempts to cover the three main categories of human rights, there are many other rights and nuances to the rights included that are not covered by this questionnaire. A more in-depth study about specific human rights might reveal a more complex pattern of support in relation to the moral foundations. As with many measures of human rights endorsement the HRQ suffers from poor discrimination ability, there are very few people that disagree with any of the human rights when presented through the HRQ. There is also confusion over the civil constraint subscale from the HRQ. Although it was designed and includes different human rights from the other subscales (Diaz-Veizades et al., 1995) it also presents them in a slightly different way such that this is sometimes used as a measure of willingness to constrain human rights (McFarland \& Mathews, 2005). Study 1 reported differences in the strengths of the relationships between individualising and binding foundations and human rights from the social security and civil constraint categories. It is not clear if these differences are due to the categories of rights or other differences in the subscales. There is significant scope for improved human rights measures that cover the categories of human rights, separate endorsement from constraint (and perhaps importance, commitment and behaviours) and provide more power to discriminate individuals. 
Similarly, there are problems with the MFQ scale, despite its widespread use to measure for moral foundations weightings. Clifford et al. (2015) summarize the limitations and produce a set of vignettes as an alternative. For study 1 the similarity in structure between the HRQ scale and part two of the MFQ scale was an advantage as it allowed the same questions to be asked about all scenarios. A set of human rights vignettes incorporating the improvements to $H R Q$ suggested above could be used in combination with the moral foundations vignettes to allow the study to be improved as well as creating a valuable new scale for human rights endorsement.

The use of word frequencies from the MFD in study 2 is also an experimental method with several limitations. Some studies have tried to address these limitations by using manual coding in addition to the raw word frequencies (e.g. Bowe \& Hoewe, 2016; Clifford \& Jerit, 2013; Graham et al., 2009). Another approach to improve the power of the analysis is to use more sophisticated techniques to extract moral foundations usage from text sources (e.g. Dehghani, Sagae, Sachdeva, \& Gratch, 2014; Sagi \& Dehghani, 2014). Study 2 selected human rights related articles simply based on the presence of the phrase "human rights." It did not attempt to measure the level of endorsement for human rights expressed in the article. More powerful techniques could supply the data necessary to analyse if the mediation results from study 1 can be reproduced using textual analysis methods, confirming that these results are not specific to the questionnaires used in study 1.

In addition, both studies 1 and 2 share the limitation that they are correlational. MFT is a theory of innate foundations of morality and theoretically any relation between MFT and human rights should be causal in the direction that individuals' moral foundations weightings cause their opinions on human rights. Neither of these studies can provide 
evidence of this causal relationship. We used a mediation analysis to demonstrate that MFT can explain differences in human rights attitudes better than political ideology, however we do not claim this is sufficient empirical evidence of a causal relationship. Some studies have used experimental techniques to investigate how arguments based on moral foundations have the ability to strengthen or change opinions (Day et al., 2014; Feinberg \& Willer, 2012) in relation to the individual's moral foundations weightings. Using these techniques could produce evidence for a causal relationship between moral foundations weightings and human rights, but as clearly explained by Bullock and $\mathrm{Ha}$ (2011), even these designs struggle to provide evidence of a causal relationships.

Despite these limitations, overall the studies present the first evidence for a relationship between human rights and moral foundations. In the introduction we briefly discussed the claims of the moral nature of human rights by the writers of the UDHR. Studies 1 and 2 both provide evidence supporting the descriptive aspect of these claims, namely that human rights attitudes are based partially on moral views. However, individual differences in morality may help to explain why human rights are still controversial despite widespread agreement on the basic principles. Political ideology has long been considered a strong predictor of human rights attitudes. We have shown that moral foundations can help to explain this relationship. The differing views on human rights across may not simply be based on political ideology, but instead differences in the morality associated with these ideologies. If people have differences in their moral weightings for different foundations, it is not possible to represent everyone's moral principles in a single set of universal rights. Haidt (2012) says that the aims of MFT include helping to explain political differences and aid understanding and communication between people with different political ideologies. 
Using MFT to explain differences in individual's endorsement of human rights may help understanding of and communication about human rights across the political spectrum.

\section{References}

Bloom, P. (2012). Moral nativism and moral psychology. In M. Mikulincer \& P. R. Shaver (Eds.), The social psychology of morality: Exploring the causes of good and evil. (pp. 7189). Washington, DC: American Psychological Association. http://doi.org/10.1037/13091-004

Bowe, B. J., \& Hoewe, J. (2016). Night and Day: An Illustration of Framing and Moral Foundations in the Oklahoma Shariah Amendment Campaign. Journalism \& Mass Communication Quarterly. http://doi.org/10.1177/1077699016628806

Bullock, J. G., \& Ha, S. E. (2011). Mediation Analysis Is Harder Than It Looks. In J. N. Druckman, D. P. Green, J. H. Kuklinski, \& A. Lupia (Eds.), Cambridge Handbook of Experimental Political Science (pp. 508-521). Cambridge: Cambridge University Press.

Clifford, S., lyengar, V., Cabeza, R., \& Sinnott-Armstrong, W. (2015). Moral foundations vignettes: a standardized stimulus database of scenarios based on moral foundations theory. Behavior Research Methods, 47(4), 1178-1198. http://doi.org/10.3758/s13428014-0551-2

Clifford, S., \& Jerit, J. (2013). How words do the work of politics: moral foundations theory and the debate over stem cell research. The Journal of Politics, 75(3), 659-671. http://doi.org/10.1017/S0022381613000492

Cohrs, J. C., Maes, J., Moschner, B., \& Kielmann, S. (2007). Determinants of human rights attitudes and behavior: A comparison and integration of psychological perspectives. Political Psychology, 28(4), 441-469.

Crowson, H. M. (2004). Human rights attitudes: Dimensionality and psychological correlates. Ethics \& Behavior, 14(3), 235-253. http://doi.org/10.1207/s15327019eb1403_2

Davies, C. L., Sibley, C. G., \& Liu, J. H. (2014). Confirmatory factor analysis of the moral foundations questionnaire. Social Psychology, 45(6), 431-436. http://doi.org/10.1027/1864-9335/a000201

Day, M. V., Fiske, S. T., Downing, E. L., \& Trail, T. E. (2014). Shifting liberal and conservative attitudes using moral foundations theory. Personality and Social Psychology Bulletin, 40(12), 1559-1573. http://doi.org/10.1177/0146167214551152

Dehghani, M., Sagae, K., Sachdeva, S., \& Gratch, J. (2014). Analyzing political rhetoric in conservative and liberal weblogs related to the construction of the "Ground Zero Mosque." Journal of Information Technology \& Politics, 11(1), 1-14. http://doi.org/10.1080/19331681.2013.826613 
Diaz-Veizades, J., Widaman, K. F., Little, T. D., \& Gibbs, K. W. (1995). The measurement and structure of human rights attitudes. The Journal of Social Psychology, 135(3), 313-328. http://doi.org/10.1080/00224545.1995.9713961

Doise, W., Spini, D., \& Clémence, A. (1999). Human rights studied as social representations in a cross-national context. European Journal of Social Psychology, 29(1), 1-29. http://doi.org/10.1002/(SICI)1099-0992(199902)29:1<1::AID-EJSP909>3.0.CO;2-\#

Doise, W., Spini, D., Jesuino, J. C., \& Ng, S. H. (1994). Values and perceived conflicts in the social representations of human rights: Feasibility of a cross-national study. Swiss Journal of Psychology, 53(4), 240-251.

Feinberg, M., \& Willer, R. (2012). The moral roots of environmental attitudes. Psychological Science, 24(1), 56-62. http://doi.org/10.1177/0956797612449177

Fetterman, A. K., Boyd, R. L., \& Robinson, M. D. (2015). Power Versus Affiliation in Political Ideology. Personality and Social Psychology Bulletin, 41(9), 1195-1206. http://doi.org/10.1177/0146167215591960

Finkel, N. J., \& Moghaddam, F. M. (Eds.). (2005). The psychology of rights and duties: Empirical contributions and normative commentaries. Washington: American Psychological Association. http://doi.org/10.1037/10872-000

Franks, A. S., \& Scherr, K. C. (2015). Using moral foundations to predict voting behavior: Regression models from the 2012 U.S. presidential election. Analyses of Social Issues and Public Policy, 15(1), 213-232. http://doi.org/10.1111/asap.12074

Getz, I. R. (1985). Moral reasoning, religion, and attitudes toward human rights. Doctoral Dissertation, University of Minnesota.

Graham, J. (2013). Mapping the moral maps: from alternate taxonomies to competing predictions. Personality and Social Psychology Review, 17(3), 237-41. http://doi.org/10.1177/1088868313492020

Graham, J., Haidt, J., Koleva, S., Motyl, M., Iyer, R., Wojcik, S. P., \& Ditto, P. H. (2013). Moral foundations theory: The pragmatic validity of moral pluralism. Advances in Experimental Social Psychology, 47, 55-130. http://doi.org/10.1016/B978-0-12407236-7.00002-4

Graham, J., Haidt, J., \& Nosek, B. A. (2009). Liberals and conservatives rely on different sets of moral foundations. Journal of Personality and Social Psychology, 96(5), 1029-1046. http://doi.org/10.1037/a0015141

Graham, J., Nosek, B. A., \& Haidt, J. (2012). The moral stereotypes of liberals and conservatives: Exaggeration of differences across the political spectrum. PLOS ONE, 7(12). http://doi.org/10.1371/journal.pone.0050092

Graham, J., Nosek, B. A., Haidt, J., Iyer, R., Koleva, S., \& Ditto, P. H. (2011). Mapping the moral domain. Journal of Personality and Social Psychology, 101(2), 366-385. 
http://doi.org/10.1097/00005053-199107000-00016

Greene, J. D. (2003). From neural "is" to moral "ought": what are the moral implications of neuroscientific moral psychology? Nature Reviews Neuroscience, 4(10), 846-849. http://doi.org/10.1038/nrn1224

Haidt, J. (2001). The emotional dog and its rational tail: a social intuitionist approach to moral judgment. Psychological Review, 108(4), 814-834. http://doi.org/10.1037/0033295X.108.4.814

Haidt, J. (2012). The righteous mind: Why good people are divided by politics and religion. New York: Pantheon Books.

Haidt, J. (2016). Are moral foundations heritable? Probably. Retrieved July 8, 2018, from http://righteousmind.com/are-moral-foundations-heritable-probably/

Haidt, J., \& Graham, J. (2007). When morality opposes justice: Conservatives have moral intuitions that liberals may not recognize. Social Justice Research, 20(1), 98-116. http://doi.org/10.1007/s11211-007-0034-z

Haidt, J., \& Graham, J. (2009). Planet of the Durkheimians, where community, authority, and sacredness are foundations of morality. In J. T. Jost, A. C. Kay, \& H. Thorisdottir (Eds.), Social and Psychological Bases of Ideology and System Justification (pp. 371-401). New York: Oxford University Press. http://doi.org/10.1093/acprof:oso/9780195320916.003.015

Hayes, A. (2013). Introduction to mediation, moderation, and conditional process analysis. New York, NY: Guilford Press. http://doi.org/978-1-60918-230-4

Iyer, R., Koleva, S., Graham, J., Ditto, P., \& Haidt, J. (2012). Understanding libertarian morality: The psychological dispositions of self-identified libertarians. PLOS ONE, 7(8). http://doi.org/10.1371/journal.pone.0042366

Kohlberg, L. (1969). Stage and sequence: The cognitive-developmental approach to socialization. In D. A. Goslin (Ed.), Handbook of socialization theory and research (pp. 347-480). Chicago: Rand McNally.

Koleva, S. P., Graham, J., Iyer, R., Ditto, P. H., \& Haidt, J. (2012). Tracing the threads: How five moral concerns (especially Purity) help explain culture war attitudes. Journal of Research in Personality, 46(2), 184-194. http://doi.org/10.1016/j.jrp.2012.01.006

Low, M., \& Wui, M. G. L. (2015). Moral foundations and attitudes towards the poor. Current Psychology. http://doi.org/10.1007/s12144-015-9333-y

McFarland, S. (2010). Personality and support for universal human rights: A review and test of a structural model. Journal of Personality, 78(6), 1735-1764. http://doi.org/10.1111/j.1467-6494.2010.00668.x

McFarland, S. (2015). Culture, individual differences, and support for human rights: A 
general review. Peace and Conflict: Journal of Peace Psychology, 21(1), 10-27. http://doi.org/10.1037/pac0000083

McFarland, S., \& Mathews, M. (2005). Who cares about human rights? Political Psychology, 26(3), 365-385. http://doi.org/10.1111/j.1467-9221.2005.00422.x

McFarland, S., Webb, M., \& Brown, D. (2012). All humanity is my ingroup: A measure and studies of identification with all humanity. Journal of Personality and Social Psychology, 103(5), 830-853. http://doi.org/10.1037/a0028724

Moghaddam, F. M., \& Vuksanovic, V. (1990). Attitudes and behavior toward human rights across different contexts the role of right-wing authoritarianism, political ideology, and religiosity. International Journal of Psychology, 25(2), 455-474. http://doi.org/10.1080/00207599008247877

Morsink, J. (1999). The Universal Declaration of Human Rights: Origins, Drafting, and Intent. Philadelphia: University of Pennsylvania Press. http://doi.org/10.9783/9780812200416

Neiman, J. L., Gonzalez, F. J., Wilkinson, K., Smith, K. B., \& Hibbing, J. R. (2016). Speaking Different Languages or Reading from the Same Script? Word Usage of Democratic and Republican Politicians. Political Communication, 33(2), 212-240. http://doi.org/10.1080/10584609.2014.969465

Nexis UK. (n.d.). LexisNexis Business and News. Retrieved from http://www.lexisnexis.com/uk/nexis

Nilsson, A., \& Erlandsson, A. (2015). The moral foundations taxonomy: Structural validity and relation to political ideology in Sweden. Personality and Individual Differences, 76, 28-32. http://doi.org/10.1016/j.paid.2014.11.049

Rest, J. R. (1986). Moral development: Advances in research and theory. New York, NY: Praeger.

Rest, J. R., Narvaez, D., Thoma, S. J., \& Bebeau, M. J. (1999). DIT2: Devising and testing a revised instrument of moral judgment. Journal of Educational Psychology, 91(4), 644659. http://doi.org/10.1037/0022-0663.91.4.644

Sagi, E., \& Dehghani, M. (2014). Measuring moral rhetoric in text. Social Science Computer Review, 32(2), 132-144. http://doi.org/10.1177/0894439313506837

Shelton, D. (Ed.). (2013). The Oxford Handbook of International Human Rights Law. New York: Oxford University Press. http://doi.org/10.1093/law/9780199640133.001.0001

Smith, K. B., Alford, J. R., Hibbing, J. R., Martin, N. G., \& Hatemi, P. K. (2017). Intuitive Ethics and Political Orientations: Testing Moral Foundations as a Theory of Political Ideology. American Journal of Political Science, 61(2), 424-437. http://doi.org/10.1111/ajps.12255

UN General Assembly. (1948). Universal Declaration of Human Rights. Retrieved from 
http://www.ohchr.org/EN/UDHR/Pages/Language.aspx?LangID=eng

Waytz, A., Dungan, J., \& Young, L. (2013). The whistleblower's dilemma and the fairnessloyalty tradeoff. Journal of Experimental Social Psychology, 49(6), 1027-1033. http://doi.org/10.1016/j.jesp.2013.07.002

Winter, J., \& Prost, A. (2013). René Cassin and Human Rights. Cambridge: Cambridge University Press. http://doi.org/10.1017/СBO9781139506700

Wolsko, C., Ariceaga, H., \& Seiden, J. (2016). Red, white, and blue enough to be green: Effects of moral framing on climate change attitudes and conservation behaviors. Journal of Experimental Social Psychology, 65, 7-19. http://doi.org/10.1016/j.jesp.2016.02.005 
Table 1 Means, Standard Deviations and Cronbach's Alpha scores for scales in Studies $1 a$ and $1 b$

\begin{tabular}{ll|rr|rr|rr}
\hline Scale & Subscale & \multicolumn{2}{|l|}{ Mean } & & \multicolumn{2}{|c|}{ Std. Deviation } & \multicolumn{2}{c}{ Cronbach's $\boldsymbol{\alpha}$} \\
\hline & & $\mathbf{1 a}$ & $\mathbf{1 b}$ & $\mathbf{1 a}$ & $\mathbf{1 b}$ & $\mathbf{1 a}$ & $\mathbf{1 b}$ \\
HRQ & Social Security & 5.58 & 5.81 & 0.90 & 1.06 & .70 & .84 \\
HRQ & Civil Constraint & 4.25 & 4.79 & 1.15 & 1.32 & .67 & .72 \\
HRQ & Equality & 6.51 & 5.77 & 0.56 & 0.82 & .51 & .31 \\
MFQ & Care & 5.07 & 5.32 & 1.15 & 1.24 & .41 & .53 \\
MFQ & Fairness & 4.91 & 5.11 & 1.05 & 1.02 & .49 & .31 \\
MFQ & Loyalty & 4.00 & 3.94 & 1.13 & 1.23 & .42 & .60 \\
MFQ & Authority & 4.27 & 4.38 & 1.14 & 1.32 & .47 & .60 \\
MFQ & Sanctity & 3.55 & 3.57 & 1.35 & 1.81 & .56 & .84 \\
\hline
\end{tabular}


Table 2 Linear regressions for individualising and binding MFs predicting HRQ scores for studies $1 \mathrm{a}$ and $\mathbf{1 b}$.

i) HRQ Civil Constraint

\begin{tabular}{|c|c|c|c|c|c|c|}
\hline \multirow[t]{2}{*}{ Study } & \multirow[t]{2}{*}{$1 a$} & \multicolumn{4}{|c|}{$1 \mathrm{~b}$} & \multirow[b]{2}{*}{$p$} \\
\hline & & SE $B$ & $p$ & $\boldsymbol{b}$ & SE $B$ & \\
\hline \multirow[t]{2}{*}{ Constant } & 7.50 & 0.72 & $<.001$ & 1.52 & 2.98 & .607 \\
\hline & {$[6.02,8.80]$} & & & {$[-4.18,7.24]$} & & \\
\hline \multirow[t]{2}{*}{ Sex } & -0.06 & 0.21 & .788 & -0.33 & 0.18 & .089 \\
\hline & {$[-0.47,0.36]$} & & & {$[-0.67,0.02]$} & & \\
\hline \multirow[t]{2}{*}{ Age } & & & & 0.19 & 0.10 & .064 \\
\hline & & & & {$[-0.02,0.39]$} & & \\
\hline \multirow[t]{2}{*}{ Individualising } & -0.07 & 0.09 & .430 & 0.32 & 0.13 & .008 \\
\hline & {$[-0.24,0.13]$} & & & {$[0.07,0.60]$} & & \\
\hline \multirow[t]{2}{*}{ Binding } & -0.71 & 0.09 & $<.001$ & -0.78 & 0.10 & $<.001$ \\
\hline & {$[-0.89 .-0.54]$} & & & {$[-0.97,-0.59]$} & & \\
\hline
\end{tabular}

ii) HRQ Equality

\begin{tabular}{|c|c|c|c|c|c|c|}
\hline \multirow[t]{2}{*}{ Study } & \multicolumn{6}{|l|}{$1 a$} \\
\hline & $b$ & SE $B$ & $p$ & $b$ & SE $B$ & $p$ \\
\hline \multirow[t]{2}{*}{ Constant } & 6.73 & 0.36 & $<.001$ & 3.74 & 1.54 & .020 \\
\hline & {$[5.99,7.32]$} & & & {$[0.91,6.94]$} & & \\
\hline \multirow[t]{2}{*}{ Sex } & 0.12 & 0.15 & .419 & 0.10 & 0.11 & .354 \\
\hline & {$[-0.14,0.40]$} & & & {$[-0.14,0.35]$} & & \\
\hline Age & & & & $\begin{array}{r}0.04 \\
{[-0.06,0.12]}\end{array}$ & 0.05 & .426 \\
\hline \multirow[t]{2}{*}{ Individualising } & 0.12 & 0.05 & .020 & 0.45 & 0.07 & $<.001$ \\
\hline & {$[0.02,0.24]$} & & & {$[0.31,0.58]$} & & \\
\hline \multirow[t]{2}{*}{ Binding } & -0.26 & 0.04 & $<.001$ & -0.36 & 0.05 & $<.001$ \\
\hline & {$[-0.35,-0,18]$} & & & {$[-0.46,-0.27]$} & & \\
\hline
\end{tabular}

iii) $H R Q$ Social Security

\begin{tabular}{|c|c|c|c|c|c|c|}
\hline \multirow[t]{2}{*}{ Study } & \multirow[t]{2}{*}{$1 a$} & \multicolumn{4}{|c|}{$1 \mathrm{~b}$} & \multirow[b]{2}{*}{$p$} \\
\hline & & SE $B$ & $p$ & $\boldsymbol{b}$ & SE $B$ & \\
\hline \multirow[t]{2}{*}{ Constant } & 3.85 & 0.65 & $<.001$ & 1.83 & 1.97 & .357 \\
\hline & {$[2.45,5.08]$} & & & {$[-2.47,6.24]$} & & \\
\hline \multirow[t]{2}{*}{ Sex } & 0.08 & 0.21 & .691 & 0.22 & 0.13 & .107 \\
\hline & {$[-0.32,0.54]$} & & & {$[-0.05,0.50]$} & & \\
\hline \multirow[t]{2}{*}{ Age } & & & & 0.01 & 0.07 & .857 \\
\hline & & & & {$[-0.11,0.14]$} & & \\
\hline \multirow[t]{2}{*}{ Individualising } & 0.48 & 0.07 & $<.001$ & 0.79 & 0.10 & $<.001$ \\
\hline & {$[0.35,0.61]$} & & & {$[0.56,0.99]$} & & \\
\hline \multirow[t]{2}{*}{ Binding } & -0.21 & 0.07 & .005 & -0.18 & 0.06 & .005 \\
\hline & {$[-0.33,-0.08]$} & & & {$[-0.30,-0.06]$} & & \\
\hline
\end{tabular}

95\% confidence intervals based on bootstrapping with 1000 samples shown in brackets.

Significant predictors at the $p<0.5$ level are shaded. 
Table 3 Reasons for agreement/disagreement in Phase 1a.

\begin{tabular}{|c|c|c|c|c|c|c|c|c|c|}
\hline \multirow[b]{2}{*}{ Category } & \multirow[b]{2}{*}{ Sub-Category } & \multirow[b]{2}{*}{ Statement } & \multirow[b]{2}{*}{$x^{2}$} & \multicolumn{6}{|c|}{ Reason for Agreement } \\
\hline & & & & Care & Fairness & Authority & Loyalty & Sanctity & None \\
\hline \multirow{15}{*}{ MFQ } & \multirow{3}{*}{ Care } & Compassion & 438 & 120 & 8 & 1 & 3 & 3 & 15 \\
\hline & & Kill & 162 & 76 & 38 & 2 & 4 & 9 & 20 \\
\hline & & Animal & 402 & 116 & 11 & 1 & 1 & 9 & 12 \\
\hline & \multirow{3}{*}{ Fairness } & Rich & 266 & 1 & 87 & 5 & 2 & 2 & 53 \\
\hline & & Justice & 436 & 13 & 120 & 3 & 3 & 3 & 8 \\
\hline & & Fairly & 571 & 4 & 134 & 1 & 4 & 1 & 6 \\
\hline & \multirow{3}{*}{ Authority } & Soldier & 121 & 20 & 17 & 73 & 25 & 4 & 11 \\
\hline & & Sex Roles & 287 & 1 & 98 & 8 & 6 & 2 & 35 \\
\hline & & Respect & 191 & 15 & 17 & 87 & 10 & 3 & 18 \\
\hline & \multirow{3}{*}{ Loyalty } & History & 99 & 10 & 19 & 15 & 35 & 4 & 64 \\
\hline & & Team & 134 & 1 & 27 & 10 & 54 & 0 & 58 \\
\hline & & Family & 88 & 26 & 27 & 8 & 64 & 6 & 19 \\
\hline & \multirow{3}{*}{ Sanctity } & Chastity & 156 & 10 & 8 & 8 & 4 & 50 & 70 \\
\hline & & Unnatural & 75 & 21 & 32 & 7 & 2 & 31 & 55 \\
\hline & & Disgust & 78 & 22 & 28 & 1 & 4 & 47 & 45 \\
\hline \multirow{16}{*}{ HRQ } & \multirow{6}{*}{ Equality } & Non & & & & & & & \\
\hline & & Discrimination & 653 & 4 & 141 & 0 & 3 & 1 & 0 \\
\hline & & Pay & 615 & 0 & 138 & 3 & 0 & 1 & 8 \\
\hline & & Wife & 426 & 4 & 118 & 2 & 4 & 1 & 21 \\
\hline & & In Marriage & 646 & 2 & 141 & 3 & 1 & 1 & 2 \\
\hline & & Marry & 631 & 0 & 139 & 2 & 2 & 0 & 6 \\
\hline & \multirow{5}{*}{ Civ-Const } & Property & 103 & 25 & 49 & 10 & 3 & 7 & 56 \\
\hline & & Censorship & 52 & 48 & 36 & 12 & 7 & 15 & 32 \\
\hline & & Pol. Prisoner & 85 & 37 & 60 & 13 & 11 & 6 & 21 \\
\hline & & Opinion & 125 & 56 & 57 & 6 & 11 & 3 & 16 \\
\hline & & Thought & 125 & 17 & 73 & 16 & 9 & 5 & 30 \\
\hline & \multirow{5}{*}{ Soc-Sec } & Unemployment & 184 & 27 & 82 & 2 & 7 & 3 & 29 \\
\hline & & Std. of Living & 358 & 35 & 107 & 0 & 1 & 4 & 3 \\
\hline & & Work Condition & 203 & 43 & 82 & 0 & 4 & 9 & 12 \\
\hline & & Aid & 188 & 59 & 68 & 0 & 4 & 1 & 18 \\
\hline & & Health & 244 & 62 & 77 & 0 & 0 & 3 & 8 \\
\hline
\end{tabular}

There is a row for each statement and a column for each possible answer. The value shown is the number of respondents that chose that answer. The chi-squared statistic per statement is also given, in all cases this is significant $p<.001$ after a Bonferroni correction for multiple comparisons $(n=30)$ is applied. Highlighted cells indicate the number of responses is 
significantly greater than chance at the $p<.05$ level using the standardised residual from the one-sample chi-squared test for the row. 
Table 4 Reasons for agreement/disagreement in Phase 1b.

\begin{tabular}{|c|c|c|c|c|c|c|c|c|c|}
\hline \multirow[b]{2}{*}{ Category } & \multirow[b]{2}{*}{ Sub-Category } & \multirow[b]{2}{*}{ Statement } & \multirow[b]{2}{*}{$x^{2}$} & \multicolumn{6}{|c|}{ Reason for Agreement } \\
\hline & & & & Care & Fairness & Authority & Loyalty & Sanctity & None \\
\hline \multirow{15}{*}{ MFQ } & \multirow{3}{*}{ Care } & Compassion & 336 & 105 & 22 & 0 & 6 & 3 & 9 \\
\hline & & Kill & 223 & 90 & 18 & 4 & 5 & 10 & 18 \\
\hline & & Animal & 459 & 120 & 3 & 1 & 2 & 11 & 8 \\
\hline & \multirow{3}{*}{ Fairness } & Rich & 348 & 2 & 104 & 2 & 1 & 3 & 33 \\
\hline & & Justice & 481 & 6 & 122 & 6 & 3 & 1 & 6 \\
\hline & & Fairly & 578 & 4 & 132 & 2 & 1 & 1 & 5 \\
\hline & \multirow{3}{*}{ Authority } & Soldier & 194 & 12 & 12 & 84 & 28 & 1 & 8 \\
\hline & & Sex Roles & 254 & 2 & 90 & 6 & 7 & 2 & 38 \\
\hline & & Respect & 320 & 9 & 13 & 104 & 5 & 2 & 12 \\
\hline & \multirow{3}{*}{ Loyalty } & History & 57 & 14 & 42 & 13 & 39 & 2 & 35 \\
\hline & & Team & 125 & 3 & 25 & 11 & 62 & 0 & 44 \\
\hline & & Family & 204 & 14 & 18 & 7 & 87 & 2 & 17 \\
\hline & \multirow{3}{*}{ Sanctity } & Chastity & 252 & 6 & 10 & 4 & 0 & 91 & 34 \\
\hline & & Unnatural & 171 & 5 & 23 & 4 & 1 & 76 & 36 \\
\hline & & Disgust & 141 & 18 & 23 & 2 & 2 & 73 & 27 \\
\hline \multirow{15}{*}{ HRQ } & \multirow{5}{*}{ Equality } & Pay & 621 & 3 & 136 & 0 & 1 & 1 & 4 \\
\hline & & Wife & 382 & 1 & 111 & 6 & 7 & 2 & 18 \\
\hline & & Mixed race & 477 & 4 & 122 & 4 & 3 & 2 & 10 \\
\hline & & Sexuality & 419 & 4 & 115 & 1 & 1 & 12 & 11 \\
\hline & & Landlord & 298 & 2 & 96 & 2 & 6 & 1 & 38 \\
\hline & \multirow{5}{*}{ Civ-Const } & Property & 154 & 13 & 56 & 5 & 2 & 7 & 62 \\
\hline & & Censorship & 85 & 23 & 61 & 15 & 6 & 9 & 31 \\
\hline & & Pol. Prisoner & 83 & 29 & 59 & 13 & 11 & 3 & 30 \\
\hline & & Opinion & 191 & 27 & 83 & 9 & 5 & 1 & 20 \\
\hline & & Thought & 123 & 11 & 68 & 28 & 5 & 3 & 29 \\
\hline & \multirow{5}{*}{ Soc-Sec } & Unemployment & 235 & 26 & 89 & 2 & 4 & 0 & 24 \\
\hline & & Std. of Living & 328 & 27 & 103 & $\infty$ & 1 & 7 & 6 \\
\hline & & Work Condition & 292 & 33 & 97 & 1 & 3 & 6 & 5 \\
\hline & & Aid & 190 & 47 & 75 & 0 & 6 & 2 & 15 \\
\hline & & Health & 227 & 48 & 81 & 0 & 4 & 2 & 10 \\
\hline
\end{tabular}

Values are the same as in Table 3 and all chi-squared statistics are significant $p<.001$ after a Bonferroni correction for multiple comparisons $(n=30)$ is applied. All chi-squared statistics are significant $p<.001$ after a Bonferroni correction for multiple comparisons $(n=30)$ is applied. 
Table 5 Effect of article type (HR or non-HR), politics (liberal or conservative), moral foundation (individualising or binding) and their interactions on MFD word frequencies.

\begin{tabular}{|c|c|c|c|}
\hline Variable & $\begin{array}{r}\operatorname{Exp}(b) \\
(95 \% \mathrm{Cl} \text { for } \operatorname{Exp}(b))\end{array}$ & $|t|$ & $p$ \\
\hline Intercept & $\begin{array}{r}0.008 \\
{[0.007,0.009]}\end{array}$ & 112.68 & $<.001$ \\
\hline Type & $\begin{array}{r}1.747 \\
{[1.564,1.951]}\end{array}$ & 9.90 & $<.001$ \\
\hline Politics & $\begin{array}{r}.915 \\
{[0.806,1.039]}\end{array}$ & 1.37 & .172 \\
\hline Foundation & $\begin{array}{r}1.290 \\
{[1.170,1.423]}\end{array}$ & 5.10 & $<.001$ \\
\hline Type*Politics & $\begin{array}{r}1.003 \\
{[0.852,1.182]}\end{array}$ & 0.04 & .970 \\
\hline Type*Foundation & $\begin{array}{r}0.723 \\
{[0.635,0.824]}\end{array}$ & 4.89 & $<.001$ \\
\hline Politics*Foundation & $\begin{array}{r}1.099 \\
{[0.949,1.273]}\end{array}$ & 1.26 & .208 \\
\hline Type*Politics*Foundation & $\begin{array}{r}1.076 \\
{[0.889,1.303]}\end{array}$ & 0.75 & .452 \\
\hline
\end{tabular}

The $b$ coefficient is shown as the incidence rate ratio (IRR) with $95 \%$ confidence intervals. 
Figure 1 Relationship between MFQ and HRQ agreement. Each chart shows points for individuals and trend lines from linear regression for the scores for binding and individualising moral foundations. The left column of charts is for Study $1 \mathrm{a}$ and the right column for Study $1 \mathrm{~b}$. The rows of charts are comparing the moral foundation scores with civil constraint, equality and social security HRQ subscale scores.

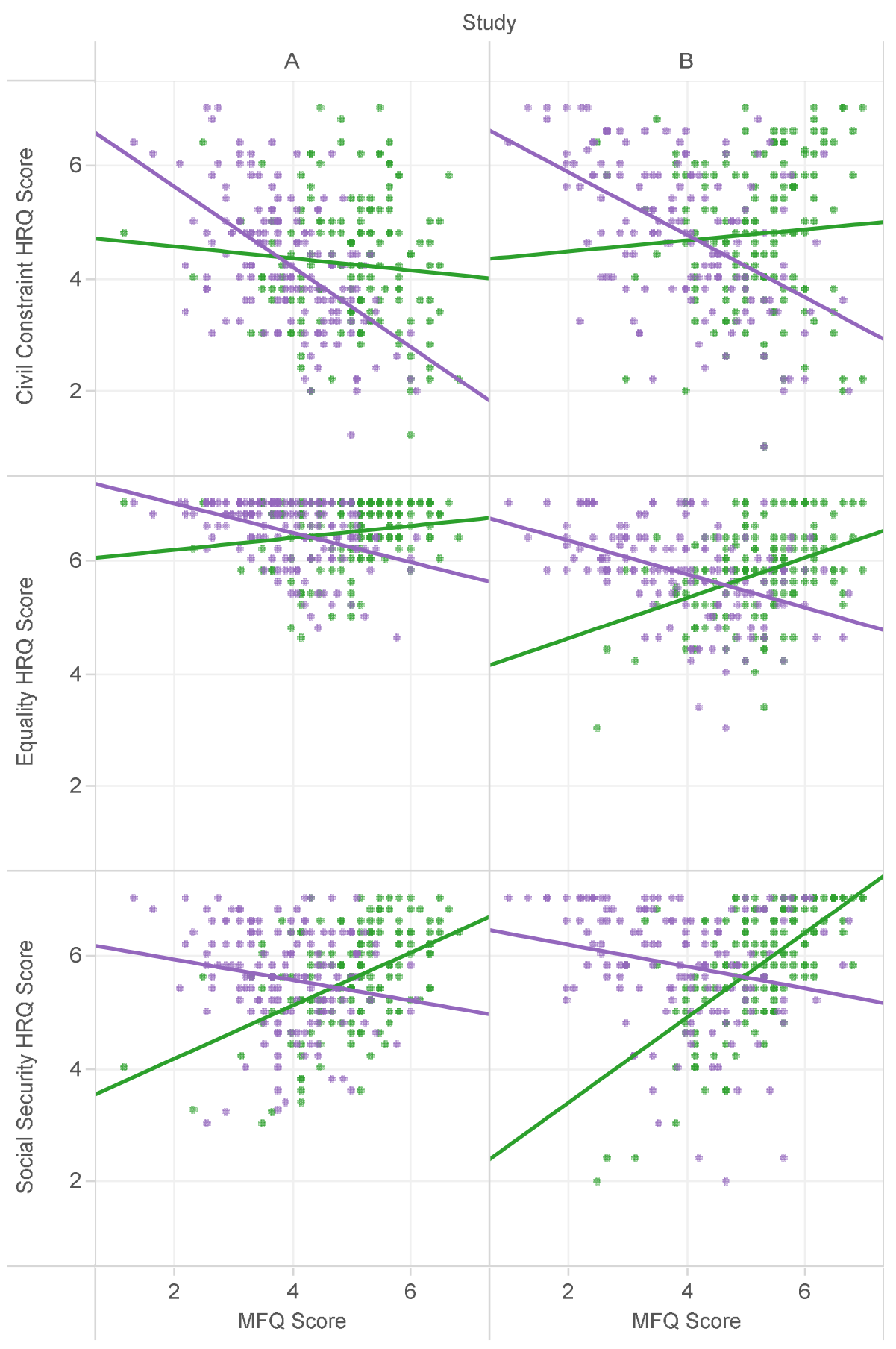

Measure Names

Binding Moral Foundations

Individualizing Moral Foundations 
Figure 2 Average human rights, individualising and binding moral foundation scores compared to political ideology

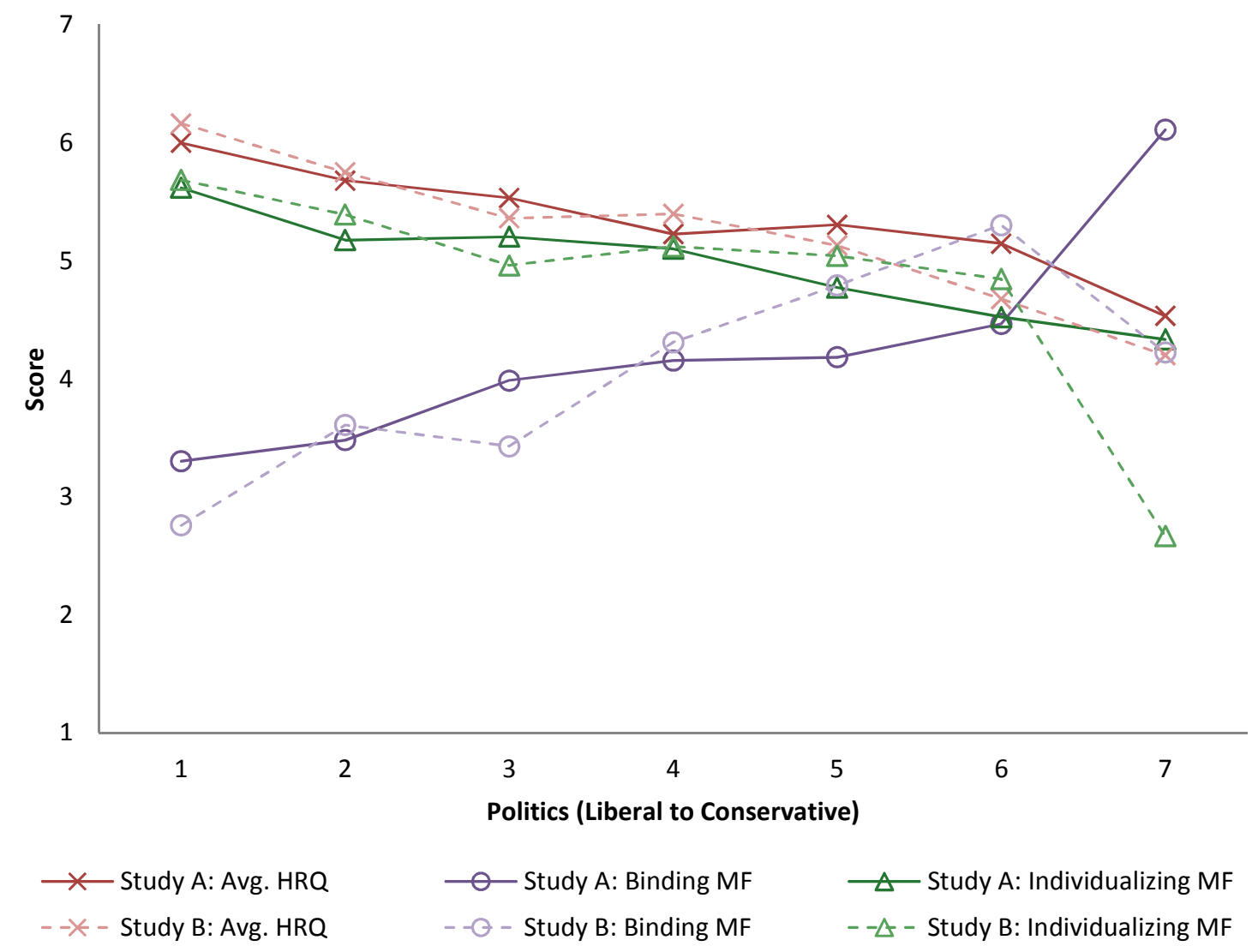


Figure 3 Summary of mediation analysis for average HRQ. In both study $1 \mathrm{a}$ and $1 \mathrm{~b}$ the relationship between politics and human rights endorsement was mediated by moral foundations. Note: A - Study 1 a, B - Study $1 b,{ }^{*} p<.05, * * p<.01,{ }^{* * *} p<.001$

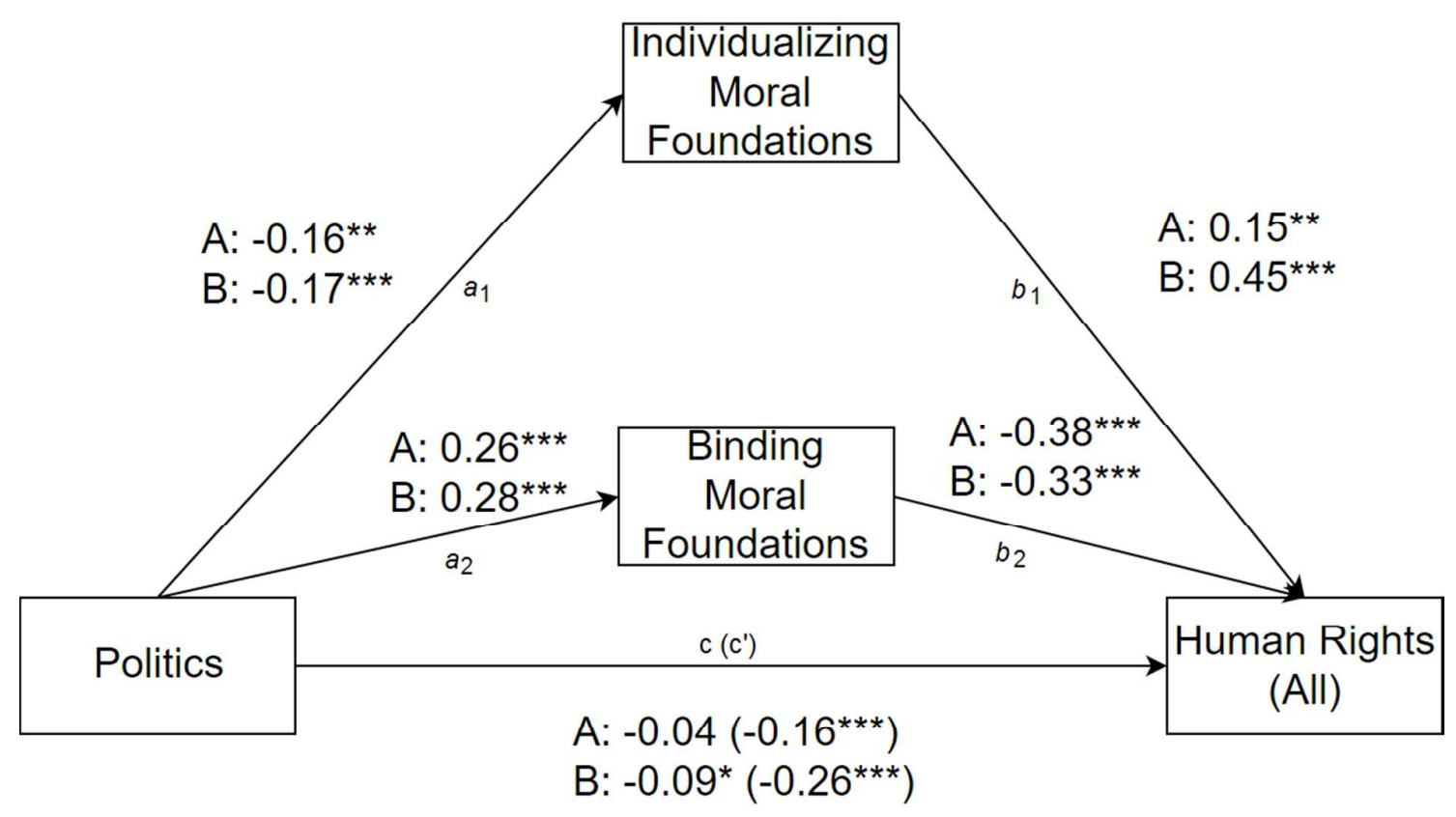


Figure 4 Frequencies of individualising and binding words from the MFD in articles related to human rights or not from liberal and conservative newspapers. Error bars show 95\% confidence intervals. Significant differences between binding and individualising word frequencies after a Holm-Bonferroni correction for multiple comparisons are indicated.

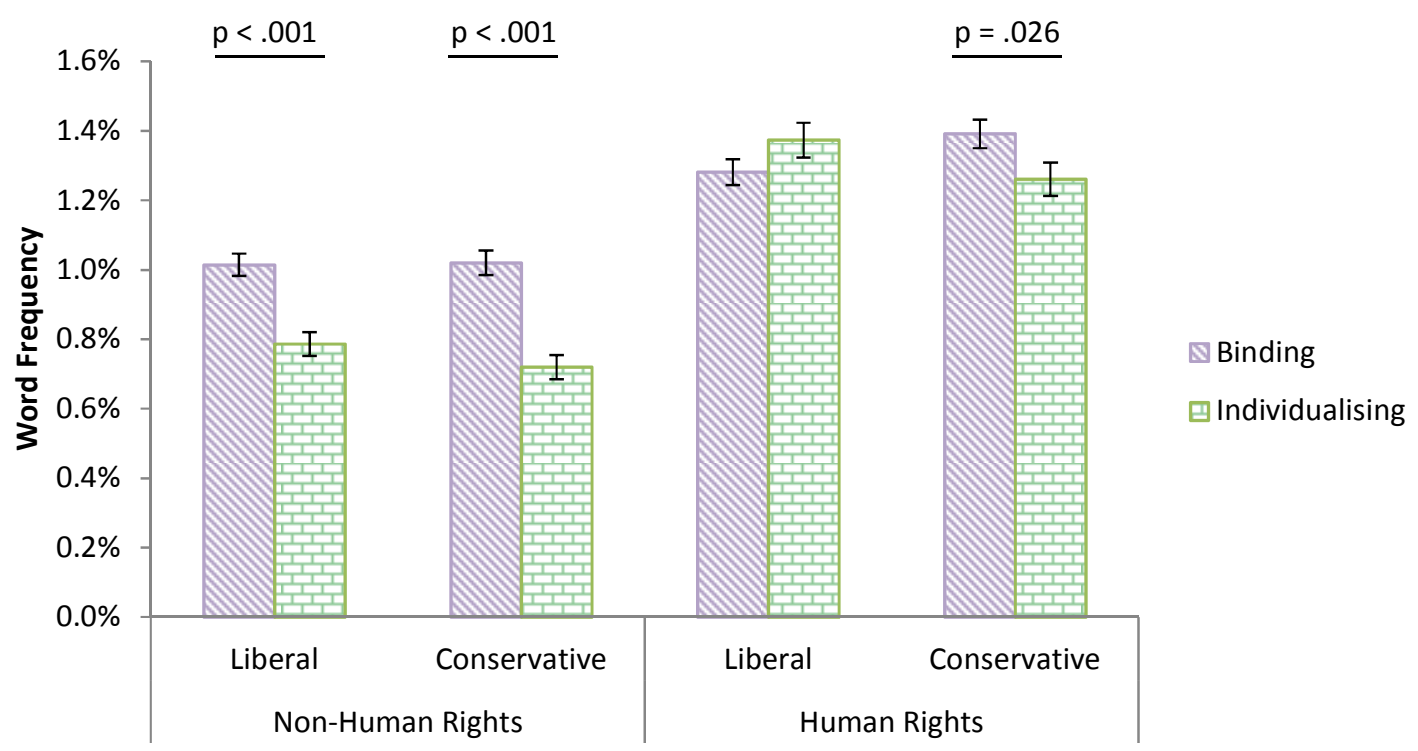




\section{Appendix S1: Study 1 Questionnaire}

Statements used in questionnaire for Study $1 \mathrm{a}$ and $1 \mathrm{~b}$. MFQ - Moral Foundation Questionnaire, HRQ - Human Rights Questionnaire, Soc-Sec Social Security, Civ-Const- Civilian Constraint

\begin{tabular}{|c|c|c|c|c|c|c|c|}
\hline Key & Statement & $\begin{array}{l}\text { Reverse } \\
\text { Coded }\end{array}$ & Scale/ Subscale & $\begin{array}{l}\text { Included in } \\
\text { Study } 1 \mathrm{a}\end{array}$ & $\begin{array}{l}\text { Included in } \\
\text { Study } 1 b\end{array}$ & $\begin{array}{l}\text { Free text } \\
\text { reasons } \\
\text { study 1a } \\
\end{array}$ & $\begin{array}{l}\text { Free text } \\
\text { reasons } \\
\text { study } 1 \mathrm{~b}\end{array}$ \\
\hline Aid & $\begin{array}{l}\text { If a person does not make enough money to support his or her family adequately, } \\
\text { the family should be aided by the government }\end{array}$ & & $\mathrm{HRQ} / \mathrm{Soc}-\mathrm{Sec}$ & Yes & Yes & Yes & Yes \\
\hline Health & $\begin{array}{l}\text { People are entitled to have the food, housing, and medical care necessary to } \\
\text { maintain their health and well being. }\end{array}$ & & $\mathrm{HRQ} / \mathrm{Soc}-\mathrm{Sec}$ & Yes & Yes & & \\
\hline Work Condition & Everyone should have the right to favourable conditions of work & & $\mathrm{HRQ} / \mathrm{Soc}-\mathrm{Sec}$ & Yes & Yes & & \\
\hline Unemployment & All persons should have protection against unemployment & & $\mathrm{HRQ} / \mathrm{Soc}-\mathrm{Sec}$ & Yes & Yes & Yes & \\
\hline Std. of Living & Everyone has the right to an adequate standard of living & & $\mathrm{HRQ} / \mathrm{Soc}-\mathrm{Sec}$ & Yes & Yes & & \\
\hline Opinion & There are times when people should be kept from expressing their opinion & Yes & $\mathrm{HRQ} /$ Civ-Const & Yes & Yes & Yes & Yes \\
\hline Pol. Prisoner & $\begin{array}{l}\text { There are times when detention of political prisoners may be necessary to ensure } \\
\text { the maintenance of social order }\end{array}$ & Yes & HRQ/Civ-Const & Yes & Yes & Yes & \\
\hline Censorship & There are times when censorship of the press is justified & Yes & HRQ/Civ-Const & Yes & Yes & & \\
\hline Property & Some people are not responsible enough to own property & Yes & HRQ/Civ-Const & Yes & Yes & & \\
\hline Thought & $\begin{array}{l}\text { There are times when people shouldn't be allowed to express their opinions freely } \\
\text { because they may endanger established ways of thought }\end{array}$ & Yes & HRQ/Civ-Const & Yes & Yes & & \\
\hline Marry & Women and men should have equal right to get married & & $\mathrm{HRQ} /$ Equality & Yes & & Yes & \\
\hline $\begin{array}{l}\text { Non } \\
\text { Discrimination }\end{array}$ & $\begin{array}{l}\text { A person's race or sex should not block the person's access to basic rights and } \\
\text { freedoms }\end{array}$ & & HRQ/Equality & Yes & & Yes & \\
\hline Pay & Everyone, without discrimination, has the right to equal pay for equal work & & HRQ/Equality & Yes & Yes & & \\
\hline In Marriage & Men and women should have equal right in a marriage & & $\mathrm{HRQ} /$ Equality & Yes & & & \\
\hline Wife & $\begin{array}{l}\text { If there is a disagreement between a husband and wife, the wife's views should be } \\
\text { considered the final word }\end{array}$ & Yes & $\mathrm{HRQ/Equality}$ & Yes & Yes & & \\
\hline Sexuality & Schools must not consider the sexuality of teachers when deciding to employ them. & & HRQ/Equality & & Yes & & Yes \\
\hline Mixed race & $\begin{array}{l}\text { Men and women of full age have a right to marry and establish a family, without } \\
\text { regard to their race, nationality or religion. }\end{array}$ & & HRQ/Equality & & Yes & & \\
\hline Landlord & $\begin{array}{l}\text { When renting a room in their house, landlords can choose tenants of the same race } \\
\text { as themselves. }\end{array}$ & Yes & HRQ/Equality & & Yes & & \\
\hline Compassion & Compassion for those who are suffering is the most crucial virtue. & & MFQ/Care & Yes & Yes & Yes & Yes \\
\hline Fairly & $\begin{array}{l}\text { When the government makes laws, the number one principle should be ensuring } \\
\text { that everyone is treated fairly. }\end{array}$ & & MFQ/Fairness & Yes & Yes & Yes & Yes \\
\hline History & I am proud of my country's history. & & MFQ/Loyalty & Yes & Yes & Yes & Yes \\
\hline
\end{tabular}




\begin{tabular}{|c|c|c|c|c|c|c|c|}
\hline Key & Statement & $\begin{array}{l}\text { Reverse } \\
\text { Coded }\end{array}$ & Scale/ Subscale & $\begin{array}{l}\text { Included in } \\
\text { Study 1a }\end{array}$ & $\begin{array}{l}\text { Included in } \\
\text { Study } 1 \mathrm{~b}\end{array}$ & $\begin{array}{l}\text { Free text } \\
\text { reasons } \\
\text { study 1a }\end{array}$ & $\begin{array}{l}\text { Free text } \\
\text { reasons } \\
\text { study } 1 b\end{array}$ \\
\hline Respect & Respect for authority is something all children need to learn. & & MFQ/Authority & Yes & Yes & Yes & Yes \\
\hline Disgust & People should not do things that are disgusting, even if no one is harmed. & & MFQ/Sanctity & Yes & Yes & Yes & Yes \\
\hline Animal & One of the worst things a person could do is hurt a defenseless animal. & & MFQ/Care & Yes & Yes & & \\
\hline Justice & Justice is the most important requirement for a society. & & MFQ/Fairness & Yes & Yes & & \\
\hline Family & $\begin{array}{l}\text { People should be loyal to their family members, even when they have done } \\
\text { something wrong. }\end{array}$ & & MFQ/Loyalty & Yes & Yes & & \\
\hline Sex Roles & Men and women each have different roles to play in society. & & MFQ/Authority & Yes & Yes & & \\
\hline Unnatural & I would call some acts wrong on the grounds that they are unnatural. & & MFQ/Sanctity & Yes & Yes & & \\
\hline Kill & It can never be right to kill a human being. & & MFQ/Care & Yes & Yes & & \\
\hline Rich & $\begin{array}{l}\text { I think it's morally wrong that rich children inherit a lot of money while poor } \\
\text { children inherit nothing. }\end{array}$ & & MFQ/Fairness & Yes & Yes & & \\
\hline Team & It is more important to be a team player than to express oneself. & & MFO/Loyalty & Yes & Yes & & \\
\hline Soldier & $\begin{array}{l}\text { If I were a soldier and disagreed with my commanding officer's orders, I would obey } \\
\text { anyway because that is my duty. }\end{array}$ & & MFQ/Authority & Yes & Yes & & \\
\hline Chastity & Chastity is an important and valuable virtue. & & MFO/Sanctity & Yes & Yes & & \\
\hline
\end{tabular}

For the multiple choice question for the reason for agreement or disagreement the options were (with order randomised except none was always placed last):

- It relates to harm or care (e.g., kindness, preventing pain to another)

- It relates to fairness or justice (e.g., honesty or increasing equality)

- It relates to loyalty (e.g., putting the interests of a group above your individual interests)

- It relates to respecting authority (e.g., obedience to a superior, respect for tradition)

- It relates to purity (e.g., cleanliness, avoiding degrading or disgusting acts)

- It is not related to any of the provided choices 
Appendix S2: Analysis of Study 1 a and $1 \mathrm{~b}$ results pooled together.

Means, Standard Deviations and Cronbach's Alpha scores for scales combined across

Studies $1 \mathrm{a}$ and $1 \mathrm{~b}$

\begin{tabular}{|c|c|c|c|c|}
\hline Scale & Subscale & Mean & Std. Deviation & $\begin{array}{l}\text { Cronbach's } \\
\alpha\end{array}$ \\
\hline HRQ & Social Security & 5.69 & 0.99 & .78 \\
\hline HRQ & Civil Constraint & 4.51 & 1.26 & .70 \\
\hline HRQ & Equality & 6.14 & .79 & .42 \\
\hline MFQ & Care & 5.19 & 1.20 & .46 \\
\hline MFQ & Fairness & 5.00 & 1.04 & .41 \\
\hline MFQ & Loyalty & 3.97 & 1.18 & .52 \\
\hline MFQ & Authority & 4.33 & 1.23 & .54 \\
\hline MFQ & Sanctity & 3.56 & 1.59 & .73 \\
\hline
\end{tabular}


Linear regressions for individualising and binding MFs predicting HRQ scores for studies 1a and $1 \mathrm{~b}$ combined

i) HRQ Civil Constraint

\begin{tabular}{lrrr} 
& $\boldsymbol{b}$ & SE $\boldsymbol{B}$ & $\boldsymbol{p}$ \\
\hline Constant & 7.28 & 0.52 & $<.001$ \\
Sex & {$[6.20,8.30]$} & & \\
Individualising & -0.50 & 0.14 & $<.001$ \\
& {$[-0.79,-0.20]$} & & \\
Binding & 0.147 & 0.08 & .070 \\
& {$[0.00,0.29]$} & & \\
& -0.64 & 0.07 & $<.001$ \\
& {$[-0.77 .-0.50]$} & & \\
\hline \multicolumn{4}{r}{$R^{2}=.50$} \\
\end{tabular}

ii) $H R Q$ Equality

\begin{tabular}{lrrr} 
& $\boldsymbol{b}$ & SE $\boldsymbol{B}$ & $\boldsymbol{p}$ \\
\hline Constant & 5.78 & 0.35 & $<.001$ \\
Sex & {$[5.08,6.46]$} & & \\
& 0.40 & 0.09 & $<.001$ \\
Individualising & {$[0.22,0.59]$} & & \\
\multirow{4}{*}{ Binding } & 0.23 & 0.06 & $<.001$ \\
& {$[0.12,0.34]$} & & \\
& -0.36 & 0.03 & $<.001$ \\
& {$[-0.42,-0.30]$} & & \\
\hline \multicolumn{4}{c}{$R^{2}=.54$} \\
\end{tabular}

iii) HRQ Social Security

\begin{tabular}{|c|c|c|c|}
\hline & $\boldsymbol{b}$ & SE $B$ & $p$ \\
\hline \multirow[t]{2}{*}{ Constant } & 2.93 & 0.43 & $<.001$ \\
\hline & {$[2.16,3.72]$} & & \\
\hline \multirow[t]{2}{*}{ Sex } & 0.08 & 0.11 & .403 \\
\hline & {$[-0.12,0.28]$} & & \\
\hline \multirow[t]{2}{*}{ Individualising } & 0.64 & 0.06 & $<.001$ \\
\hline & {$[0.51,0.76]$} & & \\
\hline \multirow[t]{2}{*}{ Binding } & -0.15 & 0.04 & $<.001$ \\
\hline & {$[-0.24,-0.07]$} & & \\
\hline
\end{tabular}

95\% confidence intervals based on bootstrapping with 1000 samples shown in brackets. 


\section{Average human rights, individualising and binding moral foundation scores compared to} political ideology for studies $1 \mathrm{a}$ and $1 \mathrm{~b}$ combined

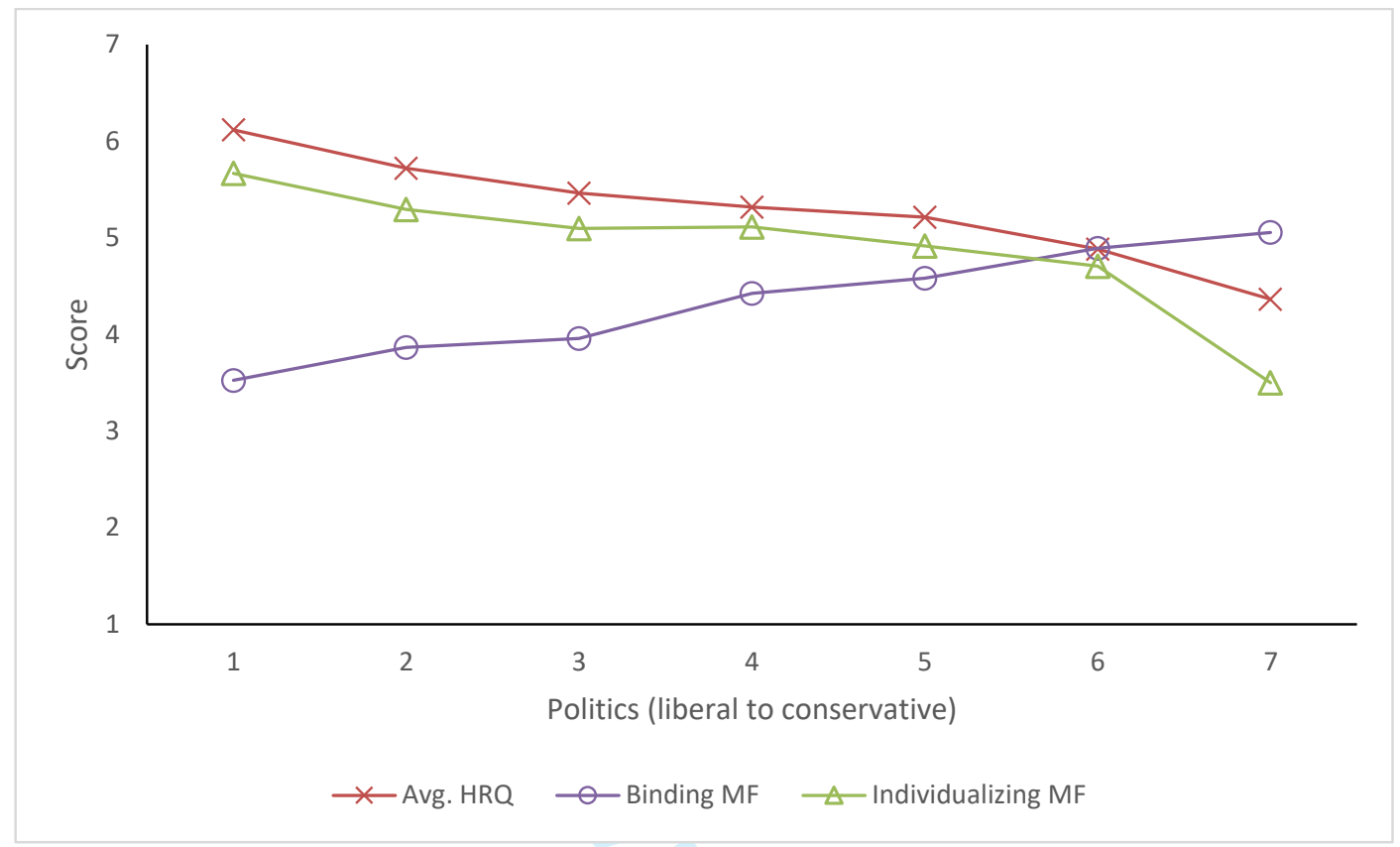

Summary of mediation analysis for average HRQ. In study $1 \mathrm{a}$ and $1 \mathrm{~b}$ combined the relationship between politics and human rights endorsement was mediated by moral foundations.

1. Politics predicts Human Rights $(H R Q)$ in a model without moral foundations

i. $\quad F(1,251)=79.28, p<.0001, R^{2}=.24$

ii. $b=-0.22, t(251)=-8.90, p<.0001$

2. Politics predict moral foundations (in a model without human rights)

a. For Individualising moral foundations

i. $F(1,251)=23.26, p<.0001, R^{2}=.08$

ii. $b=-0.17, t(251)=-4.82, p<.0001$

b. For binding moral foundations

i. $\quad F(1,251)=56.91 .06, p<.0001, R^{2}=.18$

ii. $b=0.26, t(251)=7.54, p<.0001$

3. In a model with both politics and human rights:

i. Model summary: $F(3,249)=68.03, p<.0001, R^{2}=.45$

b. Moral foundations still predict human rights:

i. Individualising foundations: $\mathrm{b}=.30, \mathrm{t}(249)=7.67, \mathrm{p}<.0001$

ii. Binding foundations: $b=-0.32, t(249)=-7.99, p<.0001$

c. The direct effect of politics predicting human rights is reduced compared to a model without moral foundations.

i. Politics: $b=-0.08, t(249)=-3.35, p=.0009$ 
d. The indirect effects of politics predicting human rights explained by both moral foundations are significant (with $95 \%$ confidence intervals):

i. Individualising foundations: $b=-0.05[-0.08,-0.03]$

ii. Binding foundations: $b=-0.08[-0.11,-0.06]$ 


\section{Appendix S3: Study 2 LexisNexis Search Terms and Number of Results}

Search terms and number of results returned for each query. The number of articles analysed for each query was limited to the most recent 50 , or fewer if there were fewer returned for the equivalent human rights query.

\begin{tabular}{|c|c|c|c|c|c|}
\hline Year & Source & Human Rights Search & $\begin{array}{l}\text { Human Rights } \\
\text { Results }\end{array}$ & Non Human Rights Search & $\begin{array}{l}\text { Non Human } \\
\text { Rights Results }\end{array}$ \\
\hline \multirow{4}{*}{$2012 / 3$} & The Guardian & $\begin{array}{l}\text { (BYLINE(Editorial) AND "human rights") AND DATE(>=2012- } \\
06-05 \text { AND }<2013-06-05)\end{array}$ & 14 & $\begin{array}{l}\text { (BYLINE(Editorial) AND NOT "human rights") AND DATE(>=2012- } \\
06-05 \text { AND }<2013-06-05)\end{array}$ & 240 \\
\hline & The Independent & $\begin{array}{l}\text { (HEADLINE("; Editorials") AND "human rights" ) AND } \\
\text { DATE(>=2012-06-05 AND <2013-06-05) }\end{array}$ & 34 & $\begin{array}{l}\text { (HEADLINE("; Editorials") AND NOT "human rights" ) AND } \\
\text { DATE(>=2012-06-05 AND <2013-06-05) }\end{array}$ & 739 \\
\hline & The Daily Telegraph & $\begin{array}{l}\text { (SECTION(Editorial) AND "human rights") AND } \\
\text { DATE(>=2012-06-05 AND <2013-06-05) }\end{array}$ & 109 & $\begin{array}{l}\text { (SECTION(Editorial) AND NOT "human rights" AND NOT } \\
\text { "cartoon") AND DATE(>=2012-06-05 AND <2013-06-05) }\end{array}$ & 2805 \\
\hline & The Daily Mail & $\begin{array}{l}\text { (HEADLINE("Daily Mail Comment") AND "human rights") } \\
\text { AND DATE(>=2012-06-05 AND <2013-06-05) }\end{array}$ & 21 & $\begin{array}{l}\text { (HEADLINE("Daily Mail Comment") AND NOT "human rights") } \\
\text { AND DATE(>=2012-06-05 AND <2013-06-05) }\end{array}$ & 102 \\
\hline \multirow{4}{*}{$2013 / 4$} & The Guardian & $\begin{array}{l}\text { (BYLINE(Editorial) AND "human rights") AND DATE(>=2013- } \\
\text { 06-05 AND <2014-06-05) }\end{array}$ & 45 & $\begin{array}{l}\text { (BYLINE(Editorial) AND NOT "human rights") AND DATE(>=2013- } \\
06-05 \text { AND <2014-06-05) }\end{array}$ & 863 \\
\hline & The Independent & $\begin{array}{l}\text { (HEADLINE("; Editorials") AND "human rights" ) AND } \\
\text { DATE(>=2013-06-05 AND <2014-06-05) }\end{array}$ & 24 & $\begin{array}{l}\text { (HEADLINE("; Editorials") AND NOT "human rights" ) AND } \\
\text { DATE(>=2013-06-05 AND <2014-06-05) }\end{array}$ & 431 \\
\hline & The Daily Telegraph & $\begin{array}{l}\text { (SECTION(Editorial) AND "human rights") AND } \\
\text { DATE(>=2013-06-05 AND <2014-06-05) }\end{array}$ & 96 & $\begin{array}{l}\text { (SECTION(Editorial) AND NOT "human rights" AND NOT } \\
\text { "cartoon") AND DATE(>=2013-06-05 AND <2014-06-05) }\end{array}$ & 2539 \\
\hline & The Daily Mail & $\begin{array}{l}\text { (HEADLINE("Daily Mail Comment") AND "human rights") } \\
\text { AND DATE(>=2013-06-05 AND <2014-06-05) }\end{array}$ & 23 & $\begin{array}{l}\text { (HEADLINE("Daily Mail Comment") AND NOT "human rights") } \\
\text { AND DATE(>=2013-06-05 AND <2014-06-05) }\end{array}$ & 120 \\
\hline \multirow{4}{*}{$2014 / 5$} & The Guardian & $\begin{array}{l}\text { (BYLINE(Editorial) AND "human rights") AND DATE(>=2014- } \\
\text { 06-05 AND <2015-06-05) }\end{array}$ & 63 & $\begin{array}{l}\text { (BYLINE(Editorial) AND NOT "human rights") AND DATE(>=2014- } \\
06-05 \text { AND <2015-06-05) }\end{array}$ & 736 \\
\hline & The Independent & $\begin{array}{l}\text { (HEADLINE("; Editorials") AND "human rights" ) AND } \\
\text { DATE(>=2014-06-05 AND <2015-06-05) }\end{array}$ & 35 & $\begin{array}{l}\text { (HEADLINE("; Editorials") AND NOT "human rights" ) AND } \\
\text { DATE(>=2014-06-05 AND <2015-06-05) }\end{array}$ & 659 \\
\hline & The Daily Telegraph & $\begin{array}{l}\text { (SECTION(Editorial) AND "human rights") AND } \\
\text { DATE(>=2014-06-05 AND <2015-06-05) }\end{array}$ & 74 & $\begin{array}{l}\text { (SECTION(Editorial) AND NOT "human rights" AND NOT } \\
\text { "cartoon") AND DATE(>=2014-06-05 AND <2015-06-05) }\end{array}$ & 2330 \\
\hline & The Daily Mail & $\begin{array}{l}\text { (HEADLINE("Daily Mail Comment") AND "human rights") } \\
\text { AND DATE(>=2014-06-05 AND <2015-06-05) }\end{array}$ & 7 & $\begin{array}{l}\text { (HEADLINE("Daily Mail Comment") AND NOT "human rights") } \\
\text { AND DATE(>=2014-06-05 AND <2015-06-05) }\end{array}$ & 40 \\
\hline \multirow{4}{*}{$2015 / 6$} & The Guardian & $\begin{array}{l}\text { (BYLINE(Editorial) AND "human rights") AND DATE(>=2015- } \\
06-05 \text { AND <2016-06-05) }\end{array}$ & 79 & $\begin{array}{l}\text { (BYLINE(Editorial) AND NOT "human rights") AND DATE(>=2015- } \\
06-05 \text { AND <2016-06-05) }\end{array}$ & 857 \\
\hline & The Independent & $\begin{array}{l}\text { (HEADLINE("; Editorials") AND "human rights" ) AND } \\
\text { DATE(>=2015-06-05 AND <2016-06-05) }\end{array}$ & 50 & $\begin{array}{l}\text { (HEADLINE("; Editorials") AND NOT "human rights" ) AND } \\
\text { DATE(>=2015-06-05 AND <2016-06-05) }\end{array}$ & 553 \\
\hline & The Daily Telegraph & $\begin{array}{l}\text { (SECTION(Editorial) AND "human rights") AND } \\
\text { DATE(>=2015-06-05 AND <2016-06-05) }\end{array}$ & 56 & $\begin{array}{l}\text { (SECTION(Editorial) AND NOT "human rights" AND NOT } \\
\text { "cartoon") AND DATE(>=2015-06-05 AND <2016-06-05) }\end{array}$ & 1396 \\
\hline & The Daily Mail & $\begin{array}{l}\text { (HEADLINE("Daily Mail Comment") AND "human rights") } \\
\text { AND DATE(>=2015-06-05 AND <2016-06-05) }\end{array}$ & 15 & $\begin{array}{l}\text { (HEADLINE("Daily Mail Comment") AND NOT "human rights") } \\
\text { AND DATE(>=2015-06-05 AND <2016-06-05) }\end{array}$ & 107 \\
\hline
\end{tabular}

